\title{
Fluorescence-Activated Cell Sorting of Embryonic Mouse and Rat Motoneurons and Their Long-Term Survival in vitro
}

\author{
Anne E. Schaffner, Paul A. St. John, and Jeffery L. Barker \\ Laboratory of Neurophysiology, NINCDS-NIH, Bethesda, Maryland 20892
}

\begin{abstract}
Motoneurons from embryonic mice and rats were labeled with retrogradely transported succinyl wheat germ agglutinin (WGA)-fluorescein isothiocyanate (FITC). After dissociation of the spinal cord, fluorescent motoneurons were isolated by flow cytometry. Sorted motoneurons were maintained for as long as 6 weeks in vitro on monolayers of astrocytes in muscle-conditioned medium. Immunocytochemical staining of the cultures for various neuronal antigens suggested that sorted motoneurons are receptive to GABAergic and glycinergic, as well as cholinergic, innervation. Many of the sorted cells were also labeled intracellularly with antibodies to choline acetyltransferase (ChAT) and GABA.
\end{abstract}

The complexities of the intact mammalian CNS make studies of the development and differentiation of individual cells and neuronal circuits exceedingly difficult. The use of cell culture has made such studies more feasible by allowing detailed cxamination of single cells with a variety of techniques (see Bottenstein and Sato, 1985). Thus, it is possible to study the development of important neuronal properties, including transmitter phenotype, the topography of transmitter receptors and ion channels, and cellular responses to transmitters. However, an obvious problem with this strategy is that it is not possible to identify different cell types once the intact CNS tissue has been dissociated. Therefore, embryonic cells studied in dissociated cell culture are normally identified only by CNS region of origin (e.g., spinal, hippocampal, cortical). Studies of the factors involved in neuronal differentiation would thus be greatly enhanced by methods to identify specific neuronal types.

Several investigators have used cell-surface-reactive antibodies to identify subpopulations of neuronal or glial cells (e.g., Barnstable, 1980; Cohen and Selvendran, 1981; Hawkes et al., 1982; McKay and Hockfield, 1982; Schachner, 1982; Derby et al., 1983; Dodd and Jessell, 1985; Fields, 1985), although in some cases the labeling by such antibodies is not restricted to morphological or functional subclasses of those cells. Others have cnriched cultures for different neuronal types by a variety of cell separation methods, most of which are based on differences in physical properties, such as size or density (see review by Schaffner and Schnaar, 1983), that do not directly correspond to neuronal type.

Received Aug. 26, 1986; revised Feb. 20, 1987; accepted Apr. 10, 1987.

The authors wish to thank Wayne Kell for excellent technical assistance with the cell sorting, G. D. Lange for developing programs to analyze and display the data, and Dr. Tu, at EY Labs, for helpful discussion and for making the FITCsuccinyl wheat germ agglutinin available to us.

Correspondence should be addressed to Dr. Anne E. Schaffner, Laboratory of Neurophysiology, National Institute of Neurological and Communicative Disorders and Stroke, NIH, Building 36, Room 2C-02, Bethesda, MD 20892.

Copyright (c) 1987 Society for Neuroscience $0270-6474 / 87 / 103088-17 \$ 02.00 / 0$
We have used a strategy, first introduced by McPheeters and Okun (1980), to specifically label spinal motoneurons by retrograde transport of a fluorescent tracer, and then to isolate labeled and dissociated motoneurons by fluorescence-activated cell sorting (FACS). This technique has been used to isolate spinal motoneurons from the embryonic chick (McPheeters and Okun, 1980; Calof and Reichardt, 1984; O'Brien and Fischbach, 1986); avian motoneurons isolated in this way have been maintained for 1 weck in culture. We have modified this method to label spinal motoneurons in embryonic mice and rats. We have found that mammalian motoneurons isolated by flow cytometry can be maintained for up to 6 weeks in culture, and we have begun to characterize the cellular properties of such isolated motoneurons. Preliminary accounts of these results have appeared previously in abstract form (Schaffner et al., 1983).

\section{Materials and Methods}

Solutions. Lyophilized, salt- and sodium azide-frec fluorescein isothiocyanate (FITC)-conjugated succinyl wheat germ agglutinin (WGA) was obtained from EY Laboratories (San Mateo, CA) and reconstituted to $50 \mathrm{mg} / \mathrm{ml}$ in mammalian saline. Saline was prepared by a modification of the method of Lance-Jones (1982) and contained (in $\mathrm{mm}$ ) $125 \mathrm{NaCl}$, $5 \mathrm{KCl}, 1.3 \mathrm{MgSO}_{4}, 2.4 \mathrm{CaCl}_{2}, 1.24 \mathrm{KH}_{2} \mathrm{PO}_{4}, 12 \mathrm{NaHCO}_{3}, 10$ glucose, and 10 HEPES. The pH was adjusted to 7.3-7.4 and the osmolarity to 320-330 mosmol with glucose as needed.

The incubation medium consisted of Minimal Essential Medium (MEM) with Earle's salts (Hazelton-Dutchland, Vienna, VA), $\mathrm{N}_{3}$ additives, and $50 \mathrm{U}(\mathrm{mg}) / \mathrm{ml}$ penicillin-streptomycin (Gibco, Grand Island, NY). Serum-free $\left(\mathrm{N}_{3}\right)$ additives were prepared by a modification of Romijn et al. (1984) and contained a final concentration of $2 \mathrm{~mm}$ glutamine (Gibco), $5 \mu \mathrm{g} / \mathrm{ml}$ insulin (Collaborative Research, Lexington, MA), $100 \mathrm{ng} / \mathrm{ml}$ corticosterone, $3 \times 10^{8} \mathrm{M}$ sodium selenite, $50 \mu \mathrm{g} / \mathrm{ml}$ transferrin, and $5 \mathrm{ng} / \mathrm{ml}$ thyroxine (all from Sigma Chemical Co., St. Louis, MO). Saline $\mathrm{D}_{1}$ SG solution, containing $10 \mathrm{~mm}$ HEPES, $17 \mathrm{~mm}$ glucose, and $22 \mathrm{~mm}$ sucrose, was made from $20 \times$ concentrate (Colorado Serum Co., Denver, $\mathrm{CO}$ ), and was adjusted to the same $\mathrm{pH}$ and osmolarity as the mammalian saline. Hanks' balanced salt solution (HBSS) was made from a $10 \times$ stock (Gibco) with the addition of $12 \mathrm{mM} \mathrm{NaHCO}_{3}$, $10 \mathrm{~mm}$ HEPES, and $0.1-1.0 \%$ BSA. Tris-buffered saline, used in immunocytochemical reactions, contained $50 \mathrm{~mm}$ Tris and $155 \mathrm{~mm} \mathrm{NaCl}$, adjusted to $\mathrm{pH} 7.6$.

Retrograde transport. Embryonic mice or rats, 13 and $15 \mathrm{~d}$ in term, respectively (or 12.5 and $14.5 \mathrm{~d}$ in term, respectively, for overnight incubations), were delivered by cesarean section, decapitated and eviscerated, and placed in mammalian saline. All 4 limbs of each embryo were injected with $50 \mathrm{mg} / \mathrm{ml}$ FITC-conjugated, succinylated WGA. Approximately $3 \mu \mathrm{l}$ was injected into each embryo. In some cases, injections of the tracer were followed by additional injections (approximately 1 $\mu \mathrm{l} / \mathrm{embryo}$ ) of 1 or $2 \mathrm{~mm} 4$-aminopyridine (Sigma) in an attempt at facilitating uptake of labeled tracer. Control embryos were injected with unconjugated succinyl WGA $(50 \mathrm{mg} / \mathrm{ml})$ or were not injected. A dorsal laminectomy was performed to expose the spinal cord directly to the oxygenated incubation medium. The embryos were placed in $75 \mathrm{~cm}^{2}$ flasks containing $40 \mathrm{ml}$ of incubation medium. For some overnight incubations, soybean trypsin inhibitor was added to the incubation medium at a final concentration of $0.05 \%$. The flasks were held in a 

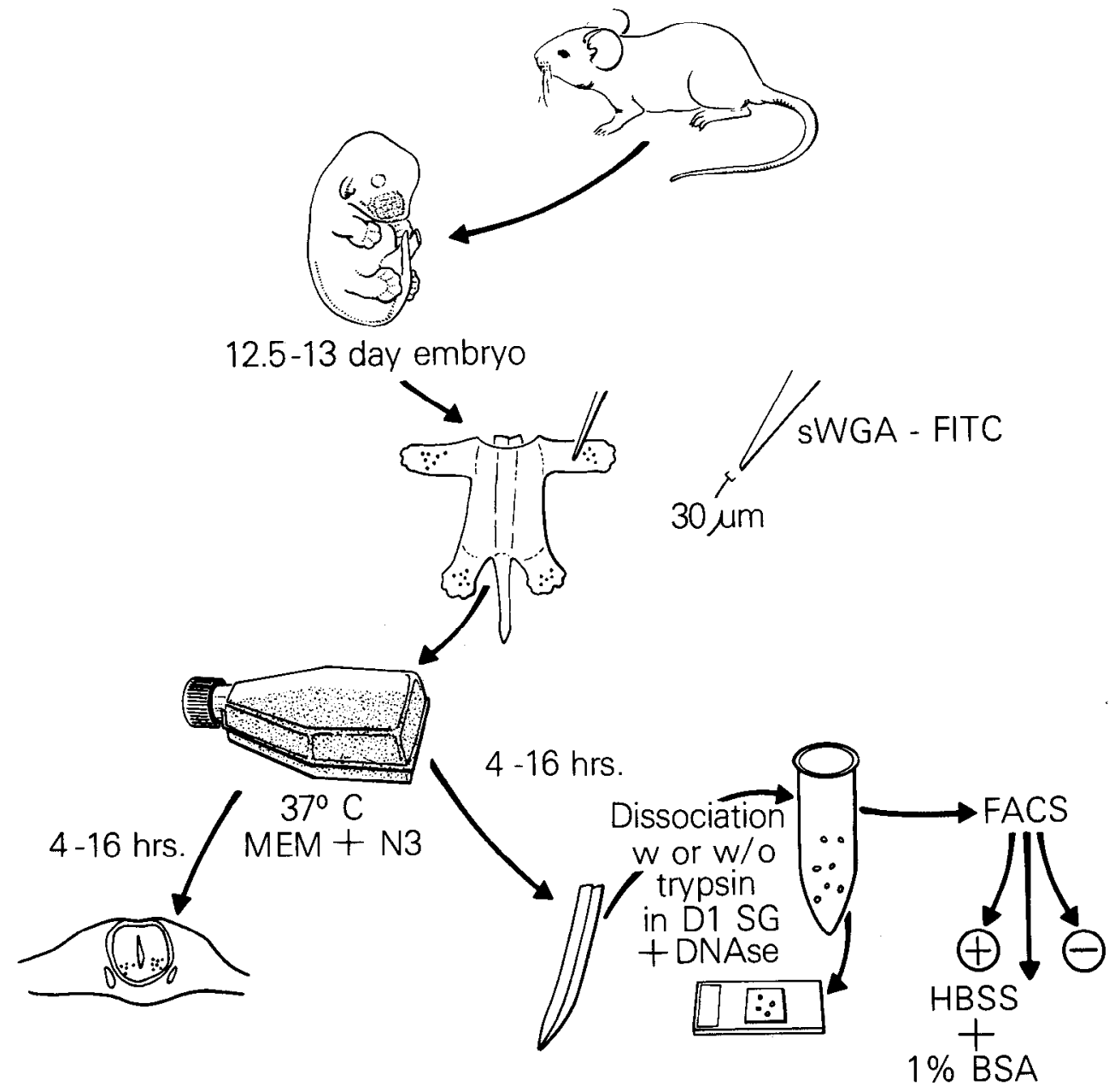

Figure 1. Illustration of the protocol used to label embryonic mouse motoneurons. After injection of the tracer and incubation in medium at $34-36^{\circ} \mathrm{C}$ for designated times, material is processed for cryostat sectioning or FACS analysis and sorting. The same techniques are used to label rat motoneurons.

$37^{\circ} \mathrm{C}$ water bath and were continuously bubbled with a mixture of $95 \%$ $\mathrm{O}_{2}$ and $5 \% \mathrm{CO}_{2}$ for 4-6 $\mathrm{hr}$ or $14-16 \mathrm{hr}$ to allow retrograde transport of tracer from the injection sites to neuronal cell bodies in the spinal cords. A schematic diagram of the protocol is shown in Figure 1.

At the end of the incubation period the spinal cords, with or without attached dorsal root ganglia, were removed, thoroughly stripped of meninges, and placed in $D_{1} S G$. The material was dissociated in $D_{1} S G$ with $0.1 \%$ trypsin (type TRL3; Cooper Biomedical, Malvern, PA) and $0.01 \%$ DNAse at $37^{\circ} \mathrm{C}$ for $15 \mathrm{~min}$. Trypsinization increased the recovery of live cells per cord by nearly $100 \%$ and increased the proportion of labeled cells by $0.5 \%$, compared to samples dissociated without enzyme. The resulting cell suspension was centrifuged at $300 \times g$ for $5 \mathrm{~min}$, resuspended in Hanks' buffer with $0.1 \%$ BSA, and passed through a $62 \mu \mathrm{m}$ Nitex filter. The final suspension typically contained $1.0-1.5 \times 10^{6}$ cells/ $\mathrm{ml}$. In some cases the injected embryos were fixed for several hours in $4 \%$ paraformaldehyde at $4^{\circ} \mathrm{C}$ in $100 \mathrm{~mm}$ phosphate buffer (pH 7.4), washed in phosphate buffer, and equilibrated in 10-30\% sucrose for 10 $\mu \mathrm{m}$ cryostat sectioning.

Cell sorting and analysis. Dissociated cells were analyzed and sorted in a Becton-Dickinson FACS 440 equipped with an argon-ion laser operating at $488 \mathrm{~nm}$ with an output of $50-400 \mathrm{~mW}$. Cells were passed through a $70 \mu \mathrm{m}$ nozzle tip. For sorting the light-scatter window was set to include only those cells in the high light-scatter region, which, as shown in a previous study, correlated with the viable cell population (St. John et al., 1986). Upon fluorescence intensity, the sorting window was set several channels above the fluorescence signal generated by spinal cord cells from control embryos. Thus, putative motoneurons were sorted according to both light-scattering and fluorescence parameters. Sorting rate was typically $1000-1500$ events/sec. Sorted cells were collected in $15 \mathrm{ml}$ centrifuge tubes precoated with Sigmacote (siliconizing agent from Sigma) and containing HBSS with $1 \%$ BSA.

Raw data were collected in LIST mode on a PDP $11 / 23$ computer (Consort 40; Becton-Dickinson). The data were presented as single- parameter frequency histograms (Fig. 6) or as dual-parameter contour plots (Fig. 5) and 3-dimensional plots (Fig. 4). For dual-parameter histograms, distributions of cell counts as a function of their light scatter and fluorescence were displayed as $64 \times 64$ bin histograms. Such histograms were made for both experimental and control samples. Difference histograms were made by subtracting corresponding bins in the control histograms from those in the experimental histograms, and negative values were ignored.

Cell culture of sorted motoneurons. Sorted cells were centrifuged at $300 \times g$ for 5 min and resuspended in plating medium. Cells were plated at a minimal density of 400 cells $/ \mathrm{mm}^{2}$ inside plastic rings that had been applied to $35 \mathrm{~mm}$ plates containing a confluent layer of non-neuronal cells (see below). Sorted motoneurons were initially plated in dialyzed mouse muscle-conditioned medium (see below) with $\mathrm{N}_{3}$ additives, $5 \%$ fetal bovine serum, 5\% heat-inactivated horse serum (Hazelton), and $50 \mathrm{U}(\mathrm{mg}) / \mathrm{ml}$ penicillin-streptomycin. After $4 \mathrm{~d}$, this medium was replaced with a maintenance medium containing the same ingredients, with the exception of fetal bovine serum and antibiotics. In some cases $10^{-5} \mathrm{M}$ fluorodeoxyuridine (FUDR) and $10^{-4} \mathrm{M}$ uridine were added at this time to inhibit further division of non-neuronal cells in the feeder layer. Medium was changed biweekly and the cultures maintained at $37^{\circ} \mathrm{C}$ in a humidified atmosphere of $8 \% \mathrm{CO}_{2}$ and $92 \%$ air.

Inserts. Insert rings of $16 \mathrm{~mm}$ I.D., $20 \mathrm{~mm}$ O.D., and $4 \mathrm{~mm}$ in height were made from Delrin plastic (DuPont, Wilmington, DE), which is nontoxic and autoclavable. The medium was removed from $35 \mathrm{~mm}$ plates containing a confluent or nearly confluent monolayer of nonneuronal cells (see below). One side of an insert ring was coated with autoclaved vacuum grease and placed in the center of each plate, and slight pressure was applied to the top of the insert to form a seal. The medium was replaced both inside and outside the ring, and the plates were returned to the incubator and used within 1 week.

Glial substrates. Cultures of rat cortical astrocytes were generated according to the method of Landis and Weinstein (1983). Cerebral 
hemispheres from 19-20 d rat embryos were dissociated in $0.1 \%$ trypsin and plated at a density of $1 \times 10^{6}$ cells in a $75 \mathrm{~cm}^{2}$ flask in MEM with $15 \%$ fetal bovine serum. When the monolayer was confluent (7-10 d), the few remaining neurons and oligodendrocytes were shaken off the surface and discarded. The astrocytes were removed from the flask with trypsin and reseeded into twenty $35 \mathrm{~mm}$ dishes. The cultures were fed MEM with serum-free additives and $5 \%$ horse serum and allowed to grow to confluency before further use. Cultures of mouse spinal cord astrocytes were obtained in a similar manner. Spinal cords from 13-15 d mouse embryos were dissociated and plated at low density in $75 \mathrm{~cm}^{2}$ flasks. When confluent, the cells were removed from the flasks with trypsin and reseeded in $35 \mathrm{~mm}$ plates.

Muscle-conditioned medium. Muscle was removed from the hindlimbs of $20 \mathrm{~d}$ mouse embryos and dissociated in $0.2 \%$ trypsin and $0.01 \%$ DNAse for $30 \mathrm{~min}$ at $37^{\circ} \mathrm{C}$, followed by the addition of $0.2 \%$ soybean trypsin inhibitor (Sigma). Cells were resuspended in $10 \mathrm{ml}$ of Dulbecco's MEM (DMEM), placed in a $100 \mathrm{~mm}$ plastic tissue culture dish, and incubated for $30 \mathrm{~min}$ at $37^{\circ} \mathrm{C}$ to allow the preferential adhesion of fibroblasts. The nonadherent cells, which included the myoblasts, were recovered, passed through lens paper to remove clumps, resuspended in DMFM containing $10 \%$ fetal calf serum and $10 \%$ horse serum, and plated at a density of $3.5-5.0 \times 10^{5}$ cells $/ 35 \mathrm{~mm}$ collagen-coated plate. After 3-4 d, when myoblasts were beginning to fuse, the medium was replaced with DMEM containing $10^{-5} \mathrm{M}$ FUDR, $10^{-4} \mathrm{M}$ uridine, and $5 \%$ horse serum; cultures were kept in this medium for $3 \mathrm{~d}$. After FUDR treatment, medium was replaced and the conditioned medium was collected every 3-4 d and frozen. Under sterile conditions, medium from several collections $(25-50 \mathrm{ml})$ was thawed, pooled, and dialyzed for 24 hr against $500 \mathrm{ml}$ of MEM with $2 \mathrm{mM}$ glutamine, $30 \mathrm{~mm}$ glucose, and $38 \mathrm{~mm} \mathrm{NaHCO}$ (Advanced Biotechnologies, Rockville, MD). The retained material was passed through a $45 \mu \mathrm{m}$ filter and used as a basis for plating and maintenance medium.

Immunocytochemistry. Cultures of motoneurons were labeled with polyclonal antisera to glutamic acid decarboxylase (GAD; a gift from Dr. Wolfgang Oertel), GABA (Immunonuclear Corp., Stillwater, MN), neuron-specific enolase (NSE; a gift from Dr. Paul Marangos), or choline $O$-acetyltransferase (ChAT; a gift from Dr. Louis Hersh), or with monoclonal antibody to the strychnine-binding protein (antibody $2 \mathrm{~b}$; a gift from Dr. Heinrich Betz). Cultures were washed briefly in serum-free medium, fixed in $4 \%$ paraformaldehyde (along with $0.1 \%$ glutaraldehyde in the case of GABA) in $0.1 \mathrm{M}$ phosphate buffer, $\mathrm{pH} 7.4$, for $1 \mathrm{hr}$ at $4^{\circ} \mathrm{C}$, and washed in PBS or Tris-buffered saline (TBS). To aid penetration of antibodies to intracellular antigens, cultures were then incubated for $5 \mathrm{~min}$ in $0.2 \%$ Triton X-100. Cultures were "blocked" (to reduce nonspecific binding of secondary antibodies) for $1 \mathrm{hr}$ at room temperature in $10 \%$ normal serum of the same species as the secondary antibody with $10 \mathrm{~mm}$ lysine in TBS and were incubated overnight at $4^{\circ} \mathrm{C}$ in primary antiserum. After several washes, cultures were incubated for $30 \mathrm{~min}$ at room temperature in a 1:50 dilution of an appropriate fluorochrome-labeled secondary antibody or an unlabeled secondary antibody [when using the peroxidase anti-peroxidase (PAP) method of Sternberger (1974)]. The secondary antibodies were affinity-purified antiIgGs (heavy and light chain) obtained from Jackson Immunoresearch (Avondale, PA). For PAP processing, the cultures were first incubated in PAP, then in $0.01 \% \mathrm{H}_{2} \mathrm{O}_{2}$ and $0.5-5 \mathrm{mg} / \mathrm{ml}$ diaminobenzidine (DAB). For ChAT staining, a biotin-avidin technique was employed, using a Vectastain rabbit IgG ABC kit (Vector Labs, Burlingame, CA). In some experiments involving GAD and ChAT immunocytochemistry, the cultures were treated overnight with $10^{-8} \mathrm{M}$ colchicine in order to block axonal transport, thereby accumulating sufficient transmitter-related enzyme in the cell bodies. Controls were incubated in nonimmune serum or in the absence of primary antibodies in PBS or TBS. Cultures were viewed in a Zeiss Photomicroscope III with an epifluorescence attachment equipped with appropriate fluorescence filters (Baltimore Instrument Co., Baltimore, MD).

Choline O-acetyltransferase assays. Assays were performed using the method of Schrier et al. (1974), with modifications as described previously (Schnaar and Schaffner, 1981).

\section{Results}

\section{Choice of retrograde tracer}

Several tracers were tested to determine which would provide a detectable fluorescence signal after short (4-6 hr) incubation periods. When FITC-labeled HRP, at a concentration of $10 \mathrm{mg}$ / $\mathrm{ml}$, was injected into embryos, spinal cord cells were labeled (in cryostat sections or FACS analysis) in only 2 out of 4 experiments. Injections of FITC-labeled WGA at the same concentration of protein gave slightly better results, perhaps because the molar ratio of fluorescein to protein was higher for the lectin than for the peroxidase, but labeling still was not intense. Higher concentrations of the tracers might have increased the fluorescence signal, but neither protein was soluble at higher concentrations in physiological solutions. However, succinylation of the WGA greatly increased its solubility without affecting the stoichiometry of FITC conjugation or its binding properties (Dr. Tu, EY Laboratories, personal communication). Succinylated WGA was therefore used for all experiments reported here. Although solutions as concentrated as $100 \mathrm{mg} / \mathrm{ml}$ were used in some experiments, a concentration of $50 \mathrm{mg} / \mathrm{ml}$ appeared to give optimal results.

\section{Localization of fluorescence in situ}

After an incubation period of 6-16 hr, the injected embryos were fixed and processed for cryostat sectioning. Intense fluorescence could be seen at the sites of injection and throughout the limbs. Fluorescent cells in the spinal cord and occasionally in the dorsal root ganglia were also evident. Labeling within the spinal cord was always confincd to the ventral aspects of the cord (Fig. 2). Fluorescence was usually seen in the dorsal root ganglia at the same spinal levels (within $\sim 50 \mu \mathrm{m}$ ) as the ventral horn labeling. Fluorescence was sometimes observed in the sheath surrounding the cord after $16 \mathrm{hr}$ incubations. However, since muscle and meninges were meticulously removed during the dissection of the spinal cord, labeled cells in these regions were not a concern. When embryos were injected on one side only, labeling was observed only on the ipsilateral side of the spinal cord, in agreement with the findings of Smith et al. (1986).

When the spinal cords from injected embryos were dissociated, microscopic examination showed the presence of variable numbers of fluorescently labeled cells (Fig. 3).

\section{FACS analysis and sorting}

The light-scatter distributions of cell suspensions derived from injected and uninjected embryos were virtually identical. However, these distributions differed consistently between samples from short (4-6 hr) and overnight incubations. In cell suspensions from 4-6 hr incubations, 3 peaks were present in the lightscatter histogram (cf. St. John et al., 1986). Microscopic examination of material sorted from each of the peaks revealed that the peak nearest the origin contained fragments of cells and subcellular debris. The middle peak consisted mostly of propidium iodide (PI)-stained, presumably dead cells and a few unstained live cells. A third, relativcly high light-scattcr pcak contained few PI-stained cells and mostly phase-bright live cells of various diameters. In contrast, cell suspensions from overnight incubations (dissociated either with or without trypsin) contained a lower proportion of dead cells. These suspensions rarely generated a middle peak in the light-scatter histogram, and in such cases the dead cells in the suspension often appeared as a shoulder on the lower end of the high light-scatter peak (Fig. 4).

The presence of fluorescent cells in samples dissociated from injected embryos was also clearly apparent after FACS analysis (Figs. 4-6). This was observed consistently in more than 50 experiments over a 2 year period. The results of 3 typical ex- 

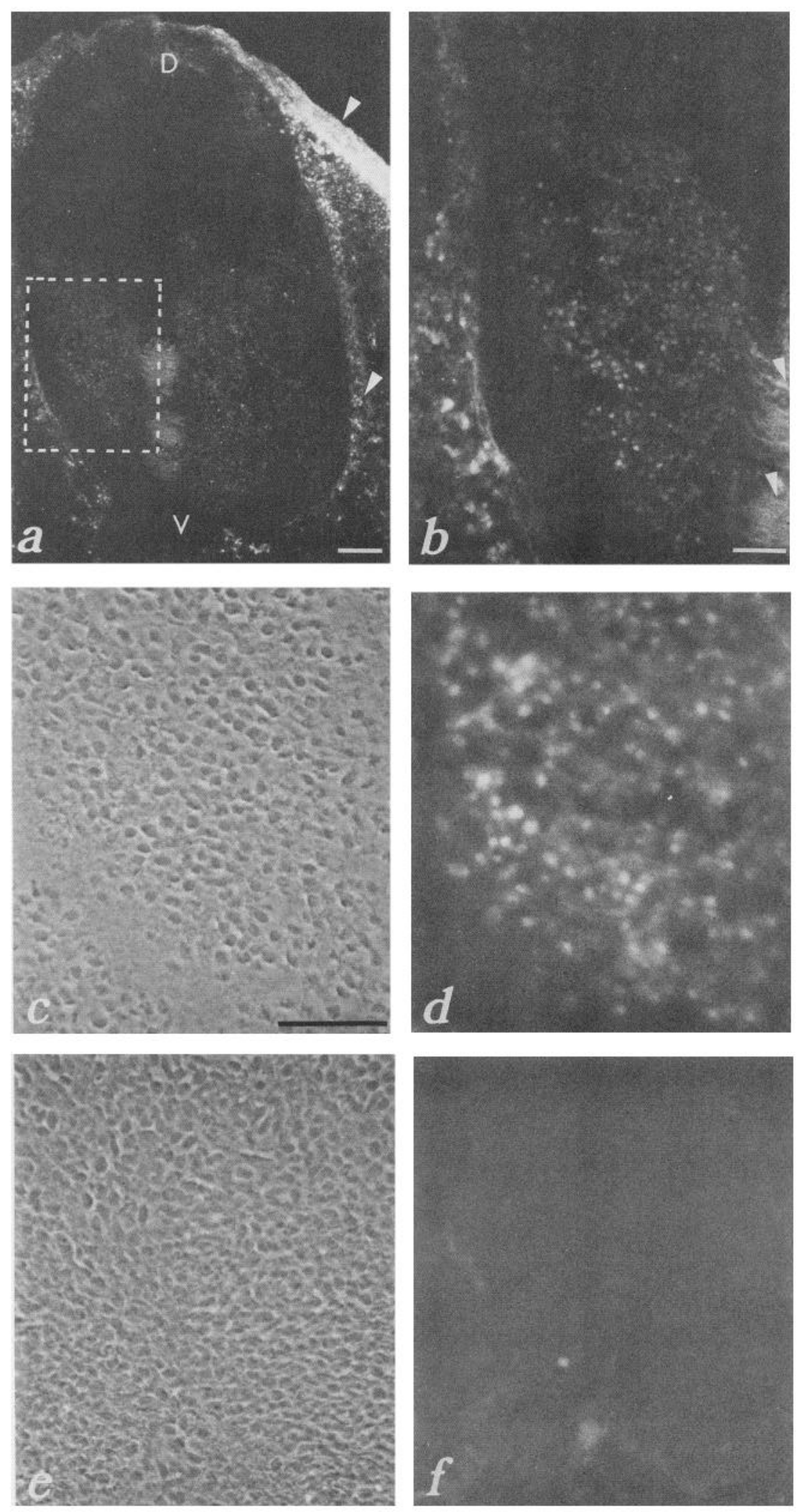

Figure 2. Photomicrographs of 10 $\mu \mathrm{m}$ frozen sections through a rat embryo injected in all 4 limbs at day 14.5 of gestation with succinylated (S)WGA-FITC. Embryos were injected and incubated overnight under the same conditions used to prepare cell suspensions for sorting, then fixed, equilibrated in sucrose, and sectioned. $a$, Low-power photomicrograph showing the area of the spinal cord and the location of fluorescence in the ventral aspects of the cord. Fluorescence can also be seen in the area of the limb buds and in the sheath surrounding the cord (arrowheads). Note the absence of fluorescence in the dorsal halves of the cord. The cord appears slightly elongated because the section was not perpendicular to the rostral-caudal plane, but was cut at a slight angle in the rostral-caudal and left-right planes. $b$, An enlargement of the enclosed area in a. Arrowheads mark what appear to be labeled processes (perhaps from motoneurons) cut in longitudinal section. Fluorescence in sheath cells is also evident. $c$, Phase-contrast, and $d$, fluorescence photomicrograph of an area in the ventral horn, showing that the label is intracellular. $e$, Phase-contrast, and $f$, fluorescence photomicrograph of an area in the dorsal horn exposed for the same amount of time, showing the absence of fluorescence in cells in this area. Calibration bar, $100 \mu \mathrm{m} \mathrm{(a);50}$ $\mu \mathrm{m}(b) ; 50 \mu \mathrm{m}(c-f)$.

periments involving overnight incubations are shown in Figures 4-6. In the dual-parameter histograms (Figs. 4, 5), a certain proportion of both intact cells and subcellular fragments from the spinal cords and dorsal root ganglia of embryos injected with fluorescent tracer exhibited fluorescence intensities that were clearly greater than those from uninjected controls. Many of the fluorescence signals were clearly associated with the peak of high light scatter, corresponding to live cells (Fig. 6). The intensity 

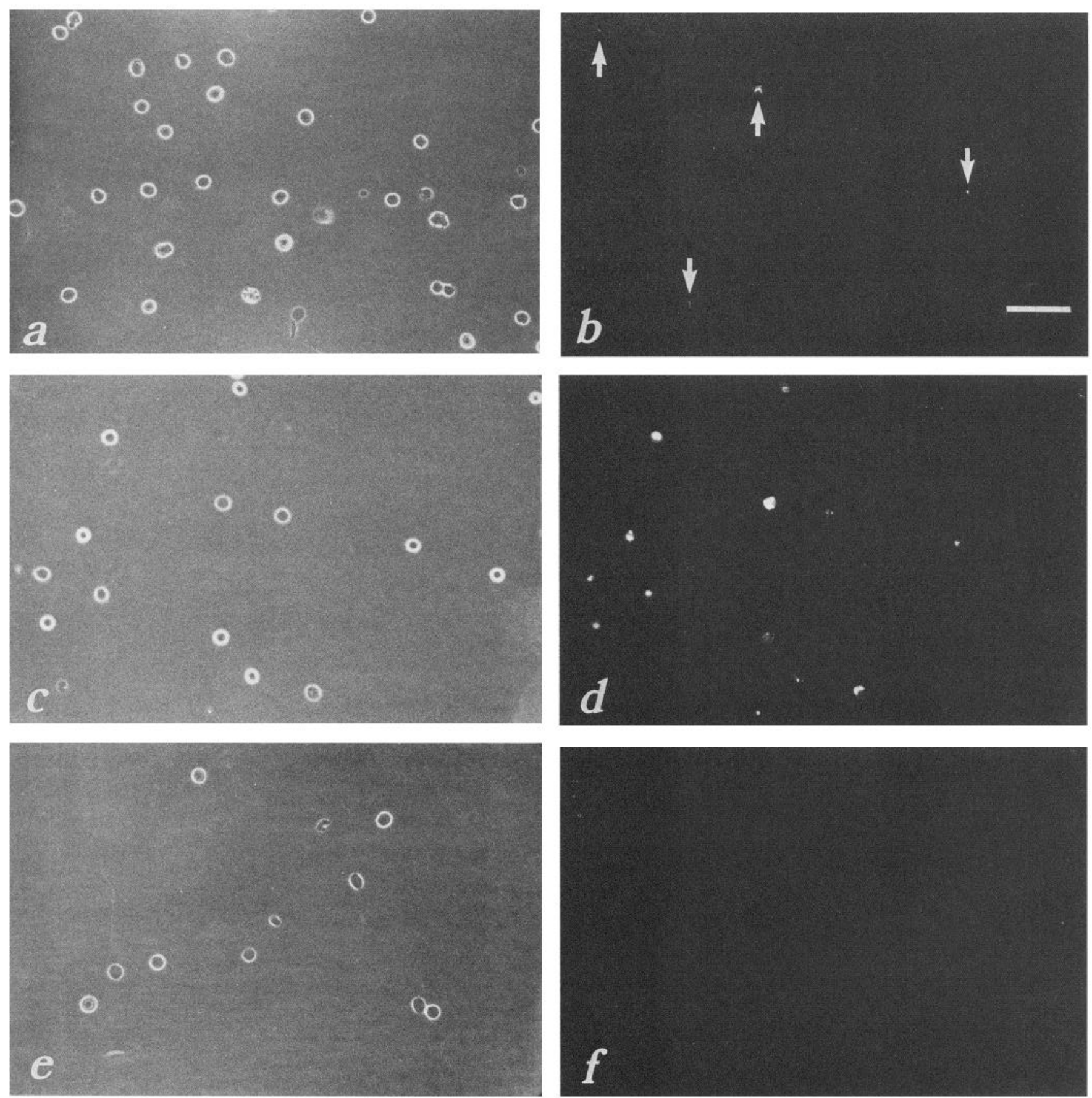

Figure 3. Dissociated rat spinal cord cells before and after isolation by cell sorting. $a$, Phase-contrast view of a suspension of cells dissociated from the spinal cords of animals that had been injected with fluorescent tracer $16 \mathrm{hr}$ prior to dissociation. This was an aliquot of the sample used for cell sorting. $b$, Fluorescence view of the same field as in $a$; fluorescence is visible in 4 of the cells in this field (arrows). $c$, Phase-contrast view of cells with high intensities of fluorescence ("positives") immediately after they had been isolated by cell sorting; these cells were considered to be putative motoneurons. $d$. Fluorescence view of the same field as in $c$; note the presence of fluorescence in 12 of the 14 cells in the field. $e$, Phasecontrast view of cells with low intensities of fluorescence ("negatives") immediately after they had been isolated by cell sorting. $f$, Fluorescence view of the same field as in $e$, with photographic exposure the same as for $d$. Note that sorted cells in $c$ and $e$ all appear phase-bright, suggesting that they remained viable after sorting. Calibration bar, $50 \mu \mathrm{m}(b)$; same for all fields.

of the fluorescence ranged from just above to well above control levels. The difference between the fluorescence distributions of material from injected and control embryos was more clearly revealed in a "difference" histogram (Fig. 4C). Since it was determined that the cells from embryos injected with nonfluorescent tracer exhibited the same light-scatter and fluorescence patterns as cells from embryos that were not injected, control samples consisted of the latter in most experiments.

Quantitative analysis of FACS data was confined to the "live cell" portion of the light-scatter histogram, since dead cells and debris were not relevant. For each experiment, fluorescence intensities of control cells were examined first, to determine a threshold that excluded more than $99 \%$ (mean, $99.4 \%$ ) of these unlabeled cells. Cells from injected embryos were then analyzed 


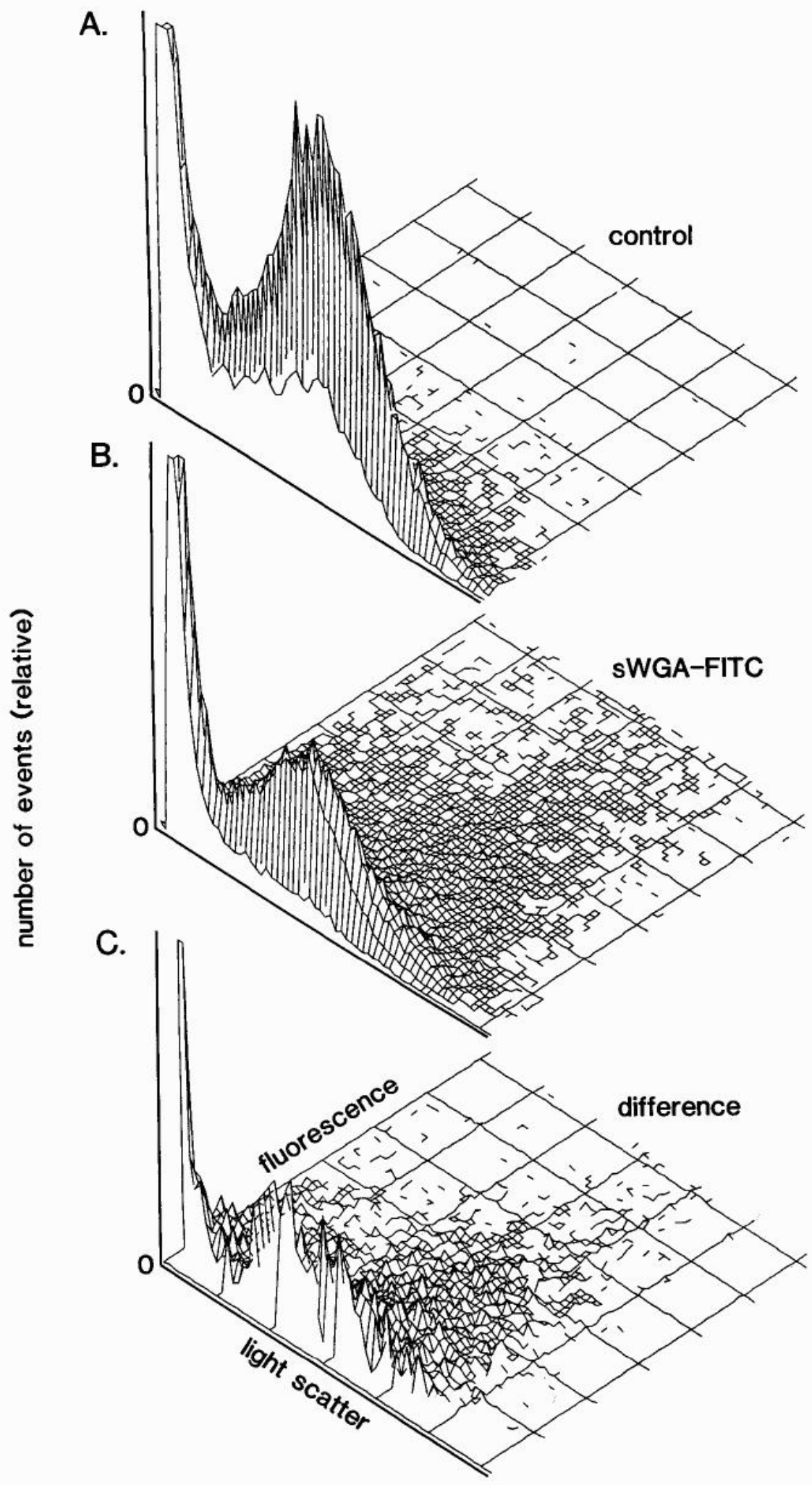

Figure 4. FACS analysis of labeling of putative motoneurons among cells dissociated from the spinal cords of $13 \mathrm{~d}$ embryonic mice. $A-C$, Dual-parameter histograms for forward-angle light scatter and FITC fluorescence intensity. $A$, Cells dissociated from uninjected control embryos display only low intensities of fluorescence that fall near the origin (0). $B$, Cells dissociated from embryos that had been injected throughout their limbs with succinylated WGA conjugated to FITC (sWGA-FITC) $16 \mathrm{hr}$ prior to dissociation. Note that many live cells display higher intensities of fluorescence than were found in control cells. $C$, "Difference" histogram generated by a channel-by-channel subtraction of $A$ from $B$ shows more clearly the presence of cells with higher intensities of fluorescence. The number of cells in each channel, on the vertical scale, is plotted on the same linear scale in $A$ and $B$ and on twice that scale in $C$.

in order to find what proportion of these cells displayed fluorescence intensities above this threshold; these cells were judged to be "labeled." When whole spinal cords from embryos given 4-6 hr incubations were processed for FACS analysis, $5 \pm 1 \%$ $(n=9)$ of the cells were found to be labeled. Since only about $0.6 \%$ of control cells displayed fluorescence intensities above the same threshold, only this number of cells in the sample from injected embryos could be accounted for by autofluorescence. Thus, among the $5 \%$ of all cells seen to be above the threshold in this sample, only approximately $10 \%$ should have been nonspecifically autofluorescent, while abøut $90 \%$ should have been specifically labeled by the fluorescent tracer.

Since the cell bodies of motoneurons are located in the ventral half of the spinal cord, we expected that it would be possible to 


\section{a. control}

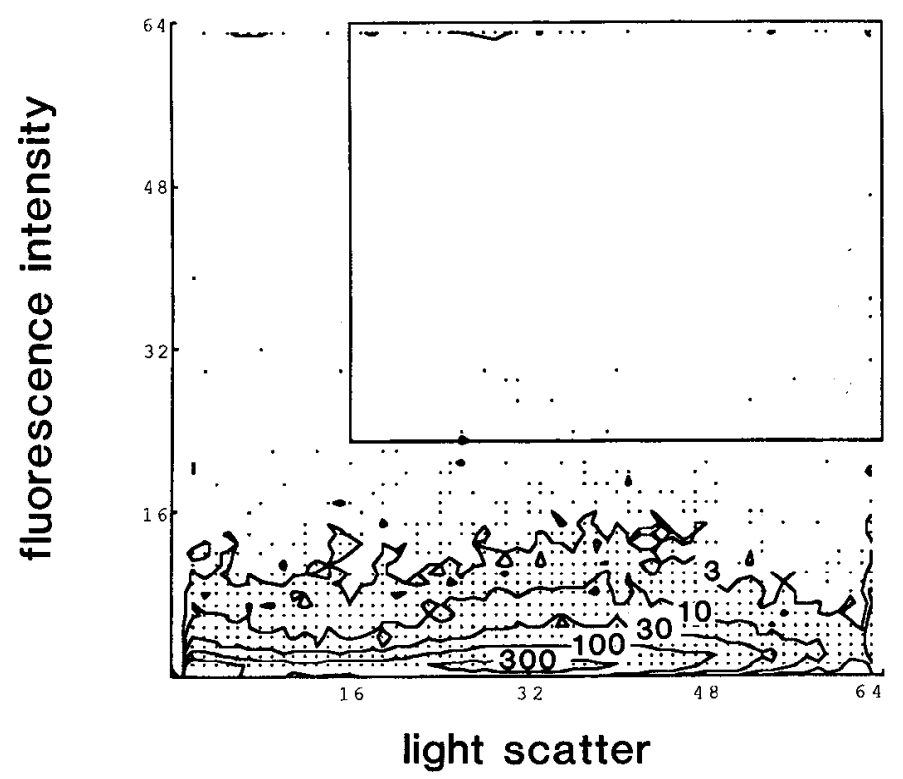

b. SWGA-FITC

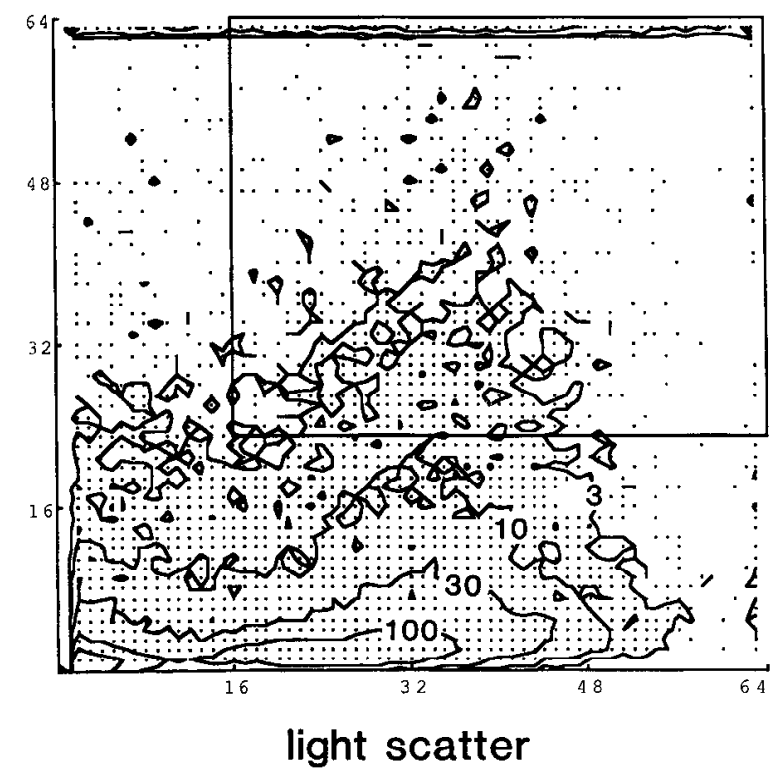

Figure 5. FACS analysis of the labeling of putative motoneurons among the cells dissociated from the ventral portions of spinal cords of $13 \mathrm{~d}$ embryonic mice. Two contour plots of dual-parameter histograms (forward-angle light scatter vs fluorescence intensity) for cells dissociated from uninjected control mice $(a)$ and from mice injected $16 \mathrm{hr}$ prior to dissociation with sWGA-FITC $(b)$. Dots mark those bins in the histograms that contained at least 2 cells. Irregular solid lines (contours) connect those bins with 3, 10, 30, 100, or 300 cells, as marked. The rectangular "window" in the upper right-hand corner of each histogram marks a typical window used for sorting. Separate analysis of the data showed that live cells were distributed through channels 16-64 of light scatter, and only these channels were considered for further analysis or sorting. In the control sample, $1.0 \%$ of the intact cells fell in the "window" marked, while $16.6 \%$ of the cells from embryos injected with tracer fell in this region. Thus, $15.6 \%$ of the intact cells in these samples were judged to be specifically labeled.

enrich for labeled cells by including only this area in the dissection. Indeed, when spinal cords were separated into dorsal and ventral halves after 4-6 $\mathrm{hr}$ of transport, the dorsal spinal cord was found to contain no labeled cells, while the proportion of labeled cells in samples from the ventral spinal cord ranged from 8 to $10 \%$. This was roughly twice the proportion found when dorsal and ventral portions of the spinal cord were analyzed together. Analysis of cells from the dorsal half of the spinal cord revealed, as expected, that this region contained no labeled cell bodies.

FACS analysis of cells from injected embryos incubated for different labeling periods showed that the total number of stained cells increased, as did the intensity of fluorescence staining, with longer incubation times. Following overnight incubation (16$20 \mathrm{hr}$ ) and dissection of the ventral halves of the spinal cords, $14 \pm 3 \%(n=8)$ of the cells in the live cell population were found to be labeled (see Fig. 6).

The same method of choosing a threshold of fluorescence intensity was used as a starting point for FACS sorting. The window used for sorting included only those cells with both light-scatter values in the range associated with live cells and fluorescence intensities at least 5-10\% higher than the threshold defined by analysis of control cells. The purity of sorted cells was increased, while the yield of sorted cells was decreased by imposing more stringent criteria for the threshold of fluorescence intensity.

From FACS analysis, the estimated $5 \%$ of all cells in the spinal cords of injected embryos that were labeled (see above) corresponded to 50-100,000 live fluorescent cells per embryo. Hemocytometer counts of the collected cells at the end of sorting showed that between 25 and $80 \%$ of the expected number were actually recovered as intact cells. Light-microscopic examination of sorted live cells revealed that fluorescence signals were associated with virtually every cell sorted (Fig. $3 b$ ) and more than $90 \%$ were phase-bright and excluded trypan blue. The loss of cells that were expected to be sorted but that were not recovered intact was probably due to several factors, including the killing of some cells by passage through the sorter, inefficiency in collection in the FACS, and loss of cells during centrifugation and resuspension after sorting.

Sensory neurons in the dorsal root ganglia were also routinely labeled by this procedure. When ganglia were removed from the spinal cords and their cells dissociated and analyzed separately, $30 \%$ of the live cells were found to be labeled. In many experiments the dorsal root ganglia were included with spinal cords during dissociation, and fluorescent ganglion neurons were sorted and plated along with labeled motoneurons.

We were able to label and sort motoneurons from both embryonic mice and rats. However, in the experiments reported here, greater emphasis was placed on the mouse because of the large body of experimental data on the morphological, electropharmacological, and immunohistochemical properties of embryonic mouse spinal cord neurons in dissociated cell culture (for a review see Nelson and Liebermen, 1981; Peacock et al., 1973).

\section{4-Aminopyridine (AP)}

We found that injection of $1 \mathrm{~mm} 4-\mathrm{AP}$ along with the fluorescent tracer for short transport times (4-6 hr) led to a consistent increase in the number of labeled cells $(8 \pm 3 \% ; n=8)$, as com- 


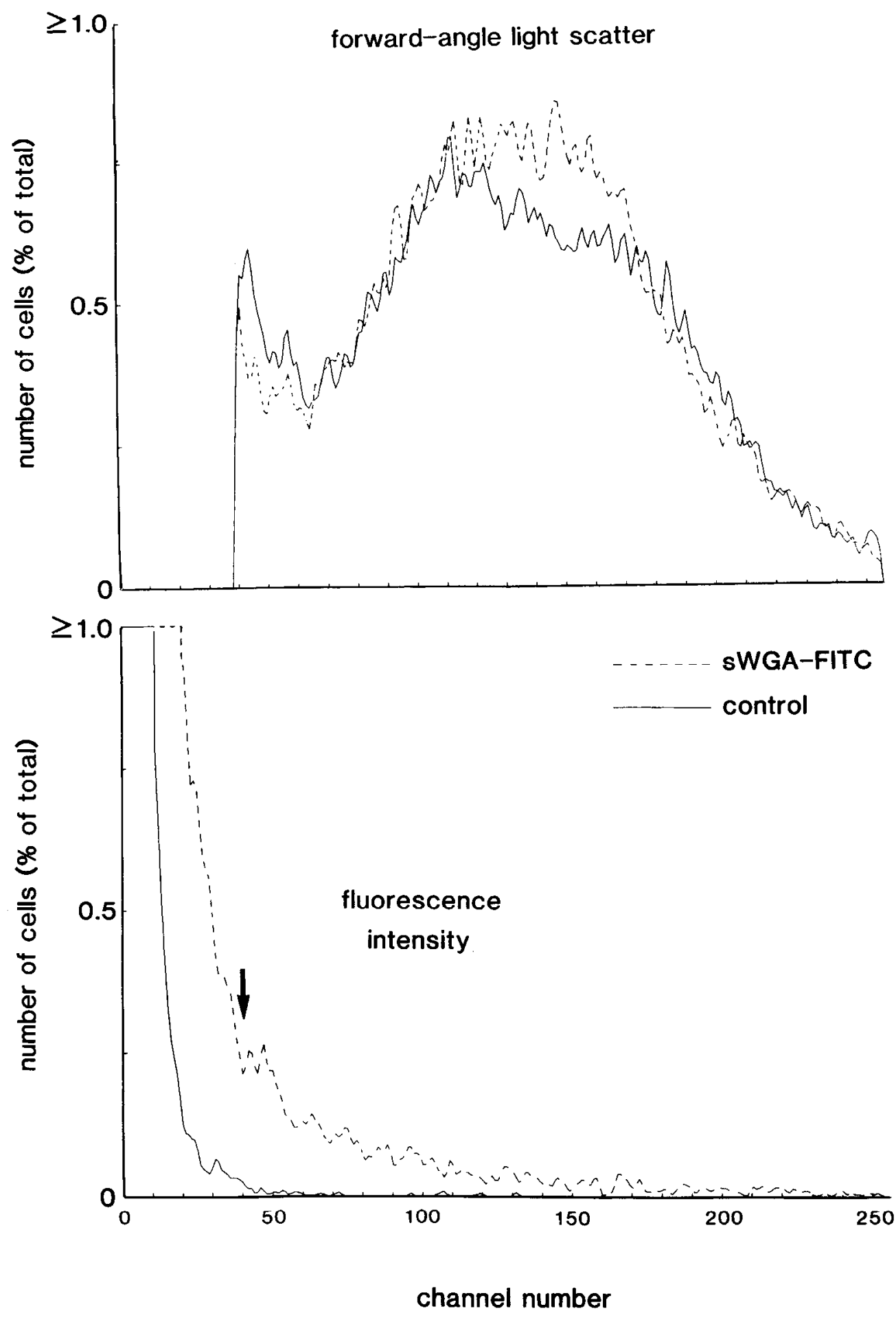

Figure 6. FACS analysis of a representative experiment in which putative motoneurons from $13 \mathrm{~d}$ embryonic mice were labeled and appeared with cells dissociated from the ventral halves of the spinal cords. Upper and lower portions display single-parameter frequency histograms for forward-angle light scatter and fluorescence intensity, respectively. In each portion, the histogram generated by cells dissociated from control embryos is shown as a solid line, and the histogram generated by cells dissociated from embryos that had been injected with fluorescent tracer (sWGA-FITC) is shown as a broken line. Note similarity of histograms in upper portion, which suggests that cells from injected embryos were not grossly altcred in morphology by the presence of the tracer dye. In the lower portion, only $0.4 \%$ of the cells from control embryos were more fluorescent than the indicated threshold (arrow at channel 40 ), while $11.0 \%$ of the cells from the embryos injected with tracer were above this threshold. pared to injections of tracer alone ( $5 \pm 1 \% ; n=9)$. However, no increase in the proportion of labeled cells was found in samples from experiments using overnight (14-16 hr) incubations, and 4-AP was therefore not used routinely for the longer incubation times.

\section{Post-sort analysis}

To determine the purity of the sorted cells, an aliquot was examined in the fluorescence microscope immediately after sorting. With short labeling times $(6 \mathrm{hr})$, fluorescence could be de- tected in only about $1 \%$ of the cells in the starting cell suspension and in only $5-10 \%$ of the cells isolated by sorting. However, reanalysis of the sorted cells on the FACS revealed that $50 \%$ of them fell into the original sorting window. Considering that photobleaching probably occurred during the first passage through the laser beam on the FACS, this represented a conservative estimate of purity. However, longer incubation times resulted in more intense labeling. In these experiments, fluorescence could be detected by microscopy in $12 \%$ of the cells in the starting sample and in over $80 \%$ of the sorted cells (Fig. 3). 

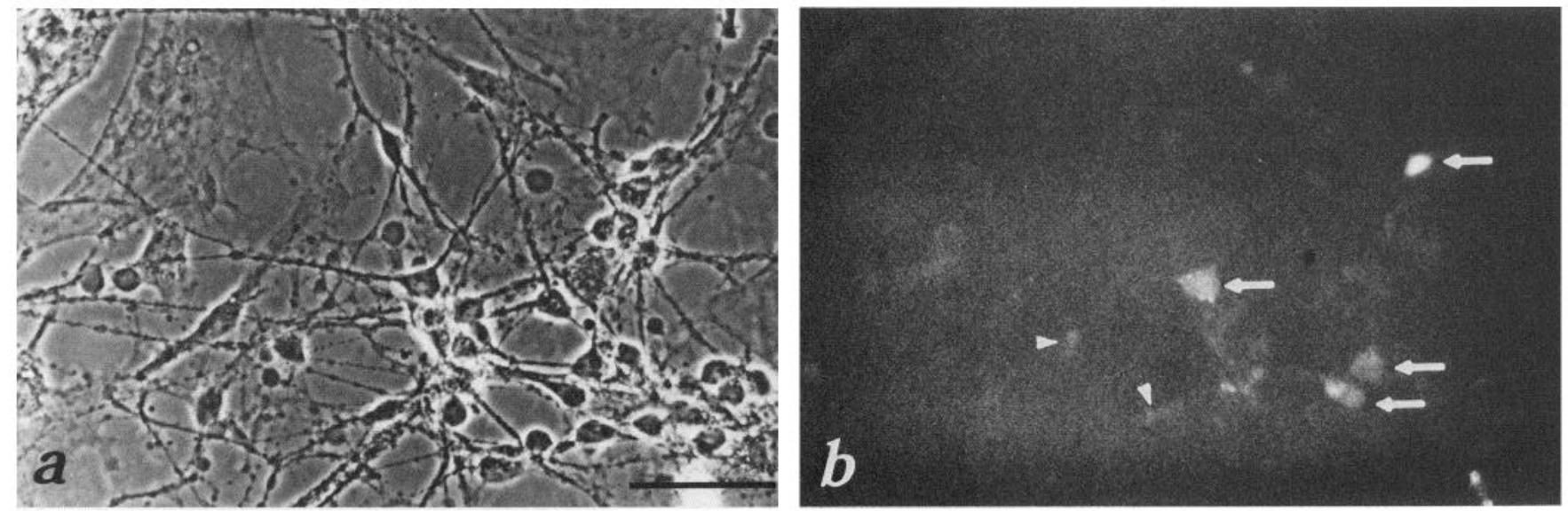

Figure 7. One day culture of putative mouse motoneurons isolated by cell sorting. $a$, Phase-contrast view of sorted putative motoneurons after $24 \mathrm{hr}$ in culture. The sorted cells have phase-bright cell bodies and long processes. $b$, Fluorescence view of the same field as in $a$ reveals that some of the cell bodies are clearly still fluorescent (arrows, arrowheads). Calibration bar, $100 \mu \mathrm{m}$.

In the same experiments, less than $1 \%$ of the "unlabeled" cells isolated by flow cytometry displayed visible fluorescence. Reanalysis on the FACS for longer incubation times was not performed. Sorting thus provided a 7-8-fold enrichment for visibly fluorescent cells.

Although fluorescent label was visibly detectable in over $80 \%$ of the sorted cells immediately after sorting, the label was detectable in only $30 \%$ of the sorted cells after $24 \mathrm{hr}$ in vitro (Fig. $7, a, b)$.

\section{Substrata for culture of sorted motoneurons}

Sorted cells did not adhere to plastic plates coated only with collagen or fibronectin, substrata used for heterogeneous cell cultures. Sorted cells did attach to plates coated with polylysine or a combination of collagen and polylysine, but failed to extend processes and did not appear to be viable after a $24 \mathrm{hr}$ period. Attempts to enhance attachment and survival on any of the noncellular substrates by growth in mouse muscle-conditioned medium were unsuccessful. However, both attachment and neurite formation were achieved when sorted motoneurons were plated onto confluent layers of non-neuronal cells derived from mouse spinal cord or rat cortex. The majority of cells in these feeders were identified as astrocytes, since they stained with antiserum against glial fibrillary acidic protein (GFAP). Sorted motoneurons grew equally well on feeders generated by either method described in Materials and Methods.

Survival of sorted motoneurons on feeders for longer than 1 week was increased by the use of mouse muscle-conditioned medium. Removal of this medium at any point during their maintenance rapidly reduced the number of surviving motoneurons. Optimal survival was obtained by plating the sorted motoneurons on astrocyte feeders in the dialyzed muscle-conditioned medium. The inserts allowed a high density of cells to be plated in a confined area in the center of a $35 \mathrm{~mm}$ dish, ensuring maximal accessibility of the sorted cells for electrophysiological and immunohistochemical studies. Sorted motoneurons could be maintained routinely under these conditions for 6 weeks in vitro.

\section{Morphology of sorted motoneurons and sensory cells}

The sorted motoneurons and sensory cells grew singly and in clumps and rapidly extended many long processes (Figs. 7-9) over a 4 week period. By field counts of "neuronal" morphologies, $75-80 \%$ of the cells differentiated into relatively large cells ( $\geq 25$ - $\mu$ m-diameter cell bodies) with thick multiple processes that were, in turn, highly branched (Fig. 9). Dorsal root ganglion neurons were also evident in the cultures and could be identified by their characteristic morphology (Fig. 9) (Peacock et al., 1973). They tended to be very phase-bright, with an eccentric nucleus, and were either bipolar or unipolar. A minority ( $20 \%)$ of the cells differentiated into small-sized multipolar neurons with cell body diameters that were typically less than $20 \mu \mathrm{m}$ (Fig. 8).

Neuron-specific enolase (NSE) immunocytochemistry (Schmechel et al., 1978, 1980) of 4-week-old cultures revealed that all of the sorted cells, including sensory neurons, contained NSE-like material, whereas none of the cells on the original feeder layer did (Fig. 10, $a, b$ ).

\section{GAD or GABA immunocytochemistry}

GAD immunocytochemistry (Oertel et al., 1981) of sorted motoneuron cultures revealed that while a majority of cells had no detectable intracellular GAD, a few cells were intensely labeled by the antibody. These 2 classes of cells appeared to be of very different size. Among the neurons with large cell bodies, which accounted for most of the cells in the cultures, none exhibited any intracellular GAD immunoreactivity, even after colchicine treatment to block anterograde transport and concentrate GAD in cell somas. In many cases, however, the large neurons were extensively invested at their soma and processes with GADpositive puncta, often so dense as to outline the cell (Fig. 11, $a$, $b)$. In contrast, among the relatively few small cells in the cultures, most were found to have intracellular GAD reactivity, suggesting that they were GABAergic and the source of the extensive network of GAD-positive neurites and the many GADpositive terminals on the larger cells. This labeling in the small cell bodies could only be observed when the cultures were pretreated with colchicine.

The conclusion that the large neurons that comprised a majority of the culture were not GABAergic was clouded, however, by an experiment using antibodies to GABA itself. This experiment revealed low-intensity intracellular GABA immunoreactivity in some of the large neurons and what appeared to be intensely labeled boutons on the somas and processes of these neurons (Fig. 11, c, d). 

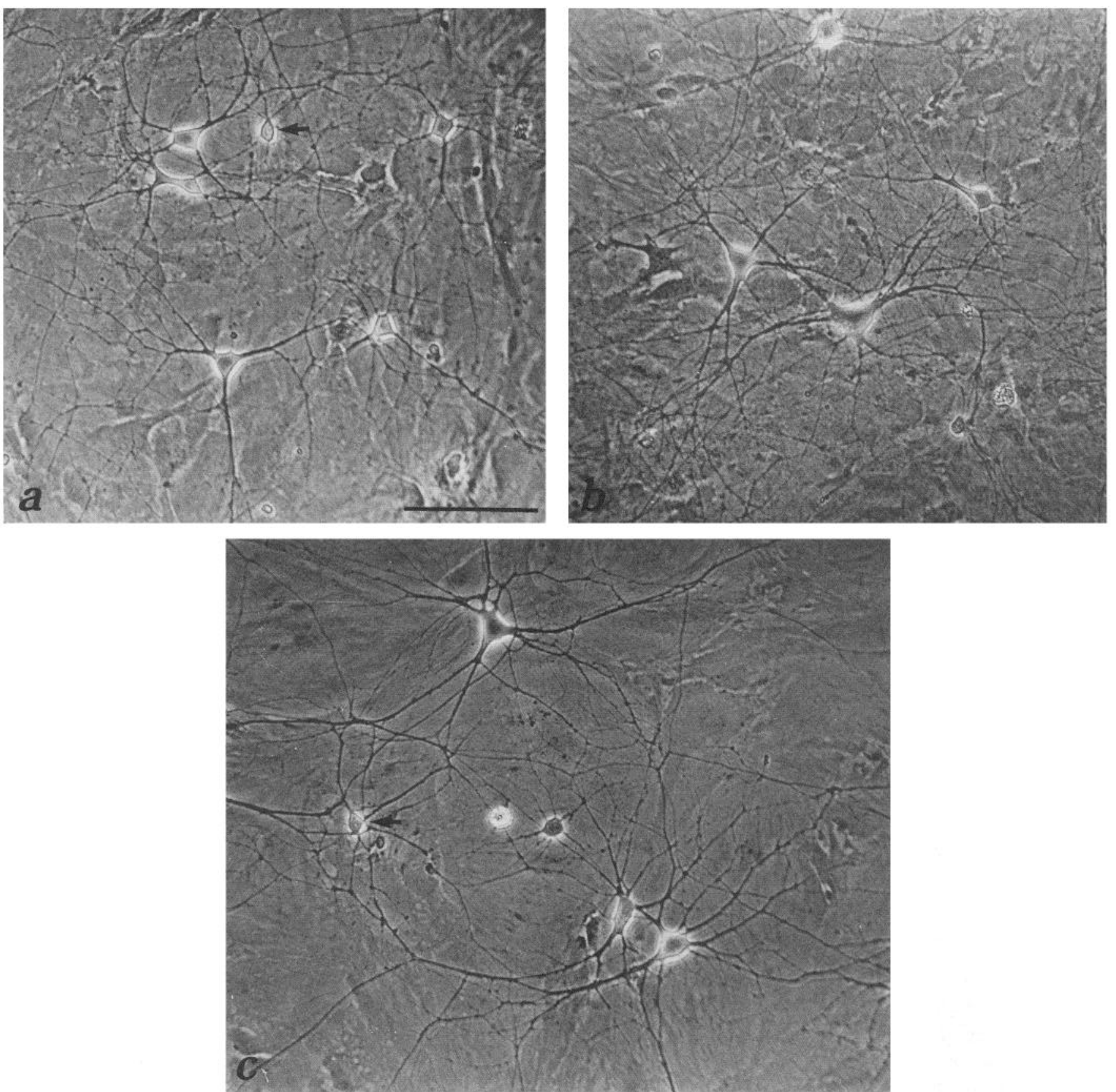

Figure 8. Two week culture of sorted putative mouse motoneurons. A variety of differently sized and shaped elements with phase-bright cell bodies is readily apparent in the representative fields shown. Process formation is quite extensive, and the majority of the cell bodies are $15-25$ $\mu \mathrm{m}$ in diameter. A few smaller-diameter, multipolar neurons present in the cultures are marked with arrows in $a$ and $c$. Calibration bar, $100 \mu \mathrm{m}$ for all fields.

\section{Anti-glycine receptor immunoreactivity}

When cultures were stained with antibodies to strychnine-binding protein, thought to be synonymous with the glycine receptor (Pfeiffer et al., 1982), many of the neurons, with the notable exception of dorsal root ganglion neurons, exhibited punctate fluorescence over both their cell bodies and proximal processes (Fig. 12). Fluorescence appeared as discrete patches, indicating possible clusters of receptors on the cell surface (see Triller et al., 1985).

\section{Cholinergic character of sorted cells}

In one experiment, live spinal cord cells from injected embryos were sorted into labeled and unlabeled populations. The cells were assayed for ChAT activity, a marker for cholinergic neurons. On a cpm/cell basis, the labeled cells showed a 4-fold enrichment for ChAT activity.

Immunohistochemical staining of the sorted motoneuron cultures, using polyclonal antibodies to ChAT (Bruce et al., 1985), indicated the presence of ChAT-immunoreactive cells. How- 

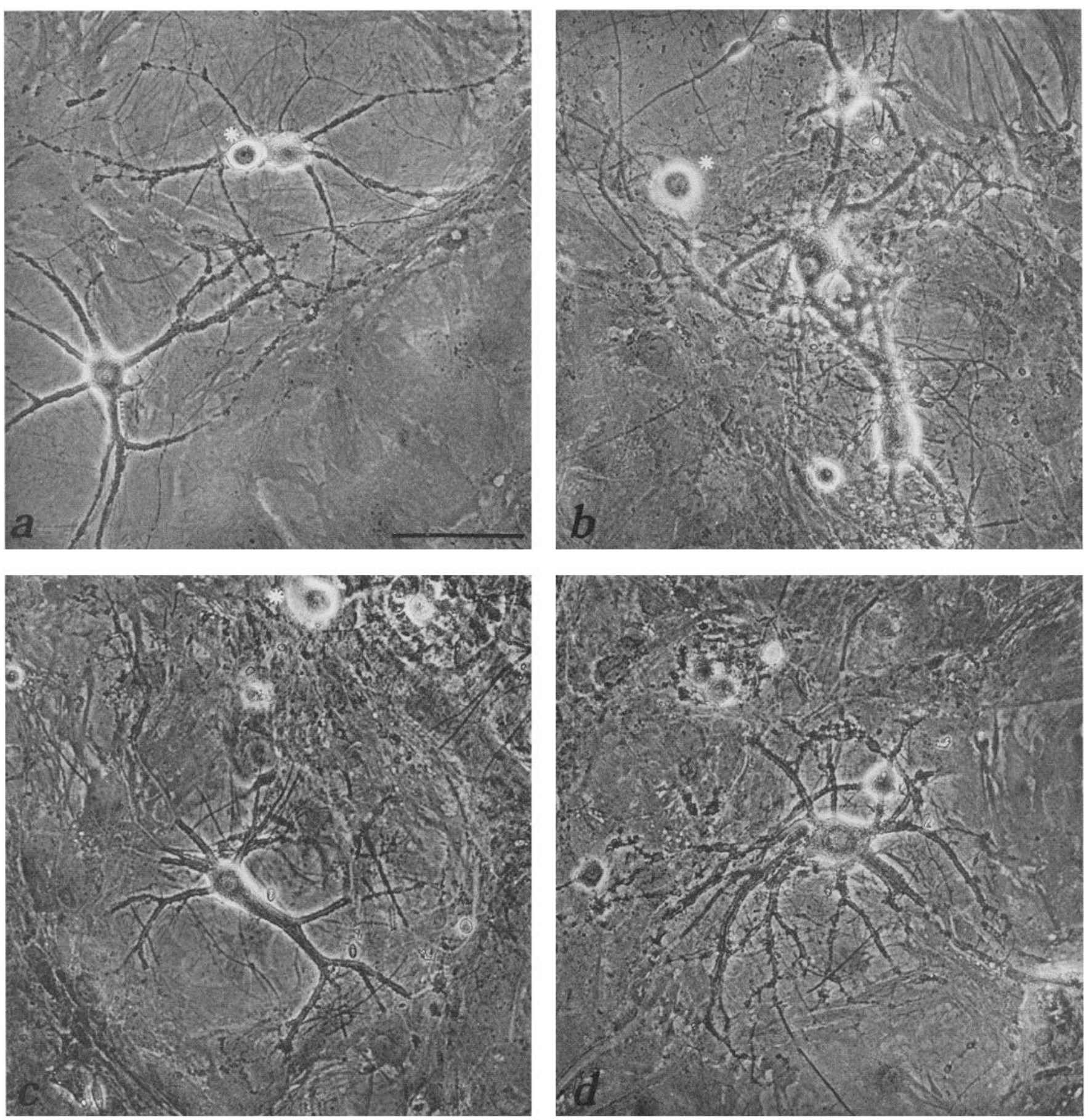

Figure 9. Four week culture of sorted putative mouse motoneurons and sensory cells. At this time, cell body size equals or exceeds $25 \mu \mathrm{m}$ in diameter. Many of the cells have irregular somal shapes, one pole of the cell body projecting as a process whose diameter rivals that of the soma (c). Processes projecting from the cell bodies are always several in number and appear thickest close to the cell body. Most of the processes branch at least once into thinner projections. Sorted dorsal root ganglion neurons can be identified by their characteristically smooth-edged, nearly circular cell bodies, whose phase-contrast reflections give a "bull's-eye" appearance. They are seen in close apposition to sorted motoneurons and are marked with an asterisk in $a-c$. Note that cells remain phase-bright and appear healthy. Calibration bar, $100 \mu \mathrm{m}$ for all fields.

ever, the fraction of immunoreactive cells in the sorted motoneuron cultures was unexpectedly low. Counts of neurons in randomly chosen fields in the sorted motoneuron-sensory cell cultures revealed that approximately $10 \%$ of the cells and their processes were intensely immunoreactive (Fig. 13, $a, c$ ), and that another $20 \%$ were slightly reactive. In many cases, large cells with little or no reaction product in their cell bodies could be seen to be covered with what appeared to be ChAT-positive boutons over their soma and processes (Fig. 13, b, d). Colchicine pretreatment did not affect the proportion of immunoreactive cells. A small number of slightly reactive dorsal root ganglion neurons was observed, but the large majority of immunoreactive cells appeared to be putative motoneurons. When whole spinal cord cultures were grown under the same conditions (on feeders 

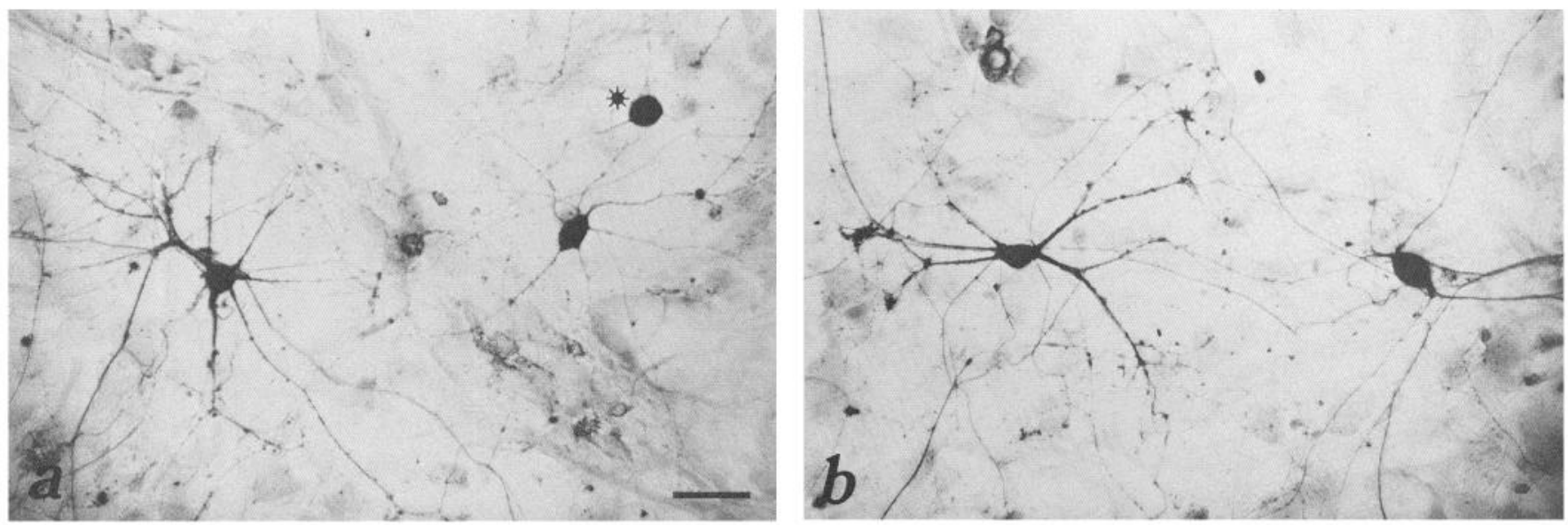

Figure 10. Neuron-specific enolase (NSE) imunocytochemistry of putative motoneurons in 4-week-old cultures (see text). $a, b$, Sorted motoneurons and possibly a dorsal root ganglion neuron (asterisk in $a$ ) labeled with antibodies against NSE. Staining indicates that sorted cells contain the neuron-specific enzyme and also reveals the extent of process formation in the cultures. Background cells are not immunoreactive. Calibration bar, $50 \mu \mathrm{m}$.

with muscle-conditioned medium), only $0.2-0.4 \%$ of the cells were immunoreactive (this study and Neale et al., 1985). Thus, sorting enriched the cultures $25-50$-fold for intensely immunoreactive cells.

\section{Discussion}

In the present study, motoneurons and sensory cells of embryonic mice and rats were labeled by retrograde transport of fluorescein-conjugated succinyl WGA, and fluorescent cells were isolated by flow cytometry. The techniques used here were similar to those employed previously to isolate motoneurons from embryonic chicks, and the number, purity, and recovery of labeled cells recorded were comparable to the values reported for embryonic chick motoneurons (McPheeters and Okun, 1980; Okun, 1981; Calof and Reichardt, 1984; O'Brien and Fischbach, 1986; see below).

A significant advance in the present study was the establishment of a protocol for the long-term survival of sorted cells in culture, i.e., over 4 weeks, compared with only 1 week for chick cells. This could reflect a species difference in the ability to survive in isolation, differences in the type of the substratum and medium used in our experiments, or the possible toxicity of the fluorochrome used by other investigators (McPheeters and Okun, 1980; Calof and Reichardt, 1984).

The age of the embryos used in these experiments was crucial. We used $13 \mathrm{~d}$ mouse embryos and $15 \mathrm{~d}$ rat embryos (age at time of sorting) for several reasons. First, the work of LanceJones (1982) on the developing mouse suggested that at $13 \mathrm{~d}$ in term, axonal projections from the motoneurons are present in the embryonic limbs. This was the earliest time that motoneurons in the mouse spinal cord could be retrogradely labeled by the injection of HRP into the limbs. Second, counts of motoneuronal cell bodies throughout embryogenesis indicate that the period of cell death in the motoneuronal pool begins at about day 14 in the mouse, with a precipitous drop in the number of cells occurring between 14 and $15 \mathrm{~d}$ in term (Flanagan, 1969; Lance-Jones, 1982). Therefore, injections just prior to this time would be expected to label the maximum number of motoneurons. We found that when mouse embryos younger than 12.5 $\mathrm{d}$ or older than $13.5 \mathrm{~d}$ were injected with tracer, the proportion of labeled cells decreased dramatically to less than $1 \%$. In the rat, there is significant loss of motoneurons between day 15 of embryogenesis and birth (Oppenheim, 1986). This timing is convenient, since spinal cord tissue taken from 12-14 d mouse embryos is the most amenable to dissociation and growth in vitro (Macdonald and Barker, 1981; Nelson and Lieberman, 1981).

We attempted to intensify the fluorescent signal in motoneurons with the addition of 4-AP to the tracer solution. 4-AP blocks depolarization-activated potassium conductances (Conner and Stevens, 1971; Segal et al., 1984), increases voltagedependent calcium conductances (Rogawski and Barker, 1983), and increases the duration of the action potential. It leads to enhancement of transmitter release at the neuromuscular junction (Thesleff, 1980), probably by affecting these conductances. The drug has been used in studies of synaptic vesicle exocytosis to increase the number of exocytotic events (Heuser, 1976) and to increase the uptake of exogenous HRP at nerve terminals (Miller and Heuser, 1984). We reasoned that if FITC-lectin uptake was coupled to membrane recycling, then 4-AP should also increase the amount of this tracer taken up at nerve terminals. Indeed, we found that the addition of 4-AP did increase the proportion of labeled cells from about 5 to about $8 \%$ in experiments with short (4-6 hr) incubation times. In experiments with longer (14-16 hr) incubation times, however, 4-AP had no effect on the proportion of cells labeled, perhaps because few motoneurons remained unlabeled under these conditions even in the absence of 4-AP.

In our experiments, fluorescent tracer that had accumulated in the cell bodies of putative motoneurons became undetectable in most cells within $24 \mathrm{hr}$ after sorting, as compared with $3 \mathrm{~d}$ or more in the results obtained by other groups working with embryonic chicks (McPheeters and Okun, 1980; Calof and Reichardt, 1984; O'Brien and Fischbach, 1986). There are several possible reasons for this difference. One is that the experiments with chicks included longer times for retrograde transport of fluorescent tracer. This presumably allowed the motoneurons to accumulate more tracer, and tracer would be retained at a detectable level for longer times. Another possible reason is that in most experiments with chick motoneurons, the tracer has been a Lucifer yellow conjugate of WGA, rather than the FITC conjugate used in our experiments. It has been noted that the 

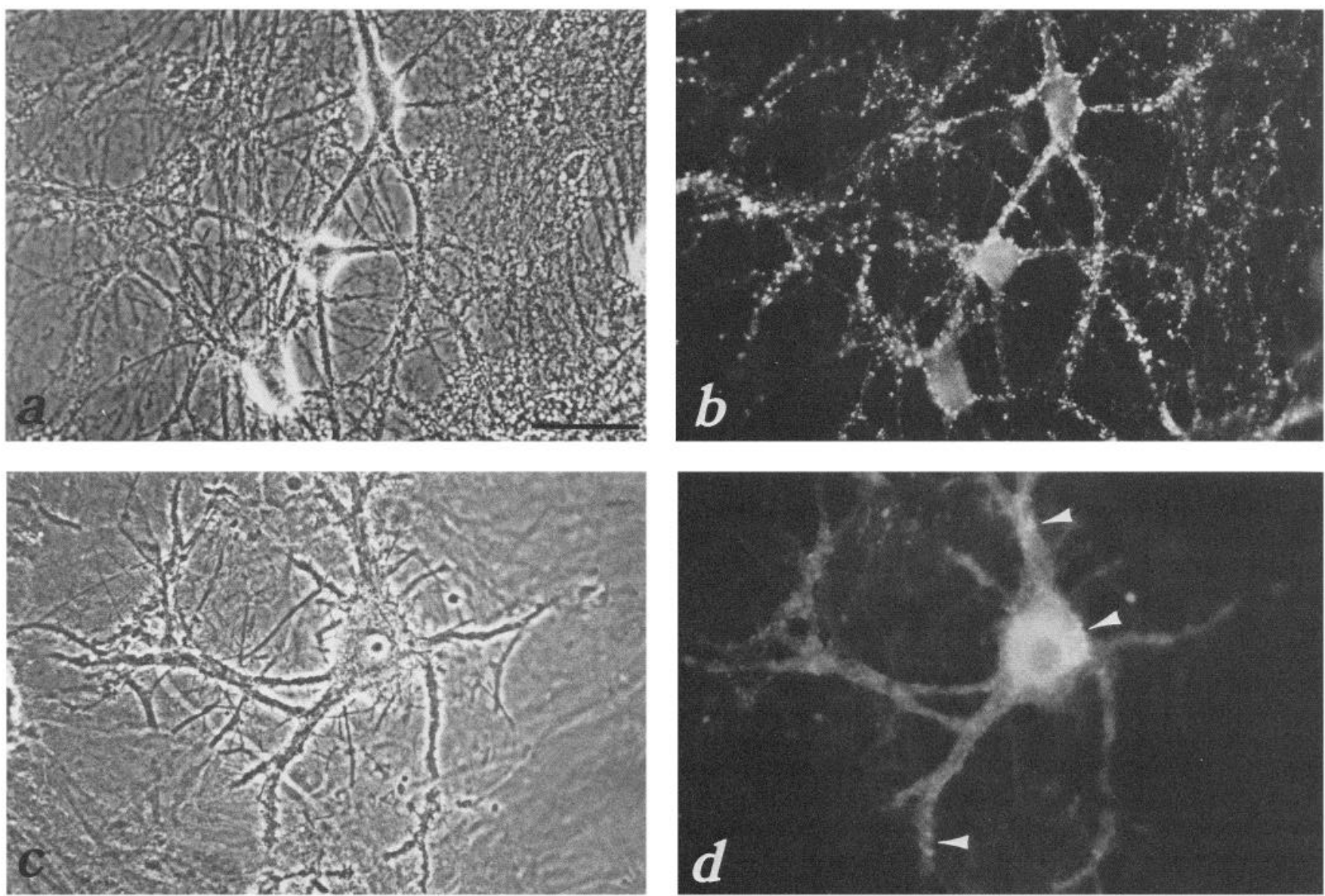

Figure 11. Cultures of enriched motoneurons fixed and labeled with antibodies against GAD and GABA. $a$, Phase-contrast photomicrograph of several sorted motoneurons in a 3-week-old culture. $b$, The same field as in $a$, showing fluorescent anti-GAD imunoreactivity. Note that the surfaces of the large, putative motoneurons are studded with GAD-containing boutons. $c$, Phase-contrast photomicrograph of a large motoneuron in a 4-week-old culture. $d$, The same field showing fluorescent anti-GABA immunoreactivity. This cell has GABA-immunoreactive boutons on its surface (arrowheads), as well as perinuclear intracellular GABA immunoreactivity. Calibration bar, $50 \mu \mathrm{m}$ for all fields.

fluorescence associated with Lucifer yellow is more resistant to fading under exciting illumination than is the fluorescence in FITC-filled neurons (Stewart, 1978, 1981). It is also possible that the FITC conjugate is degraded more rapidly within the labeled cells, that free FITC released during degradation of its lectin conjugate is not retained in cells as long as is free Lucifer yellow, or simply that motoneurons from the different species degrade transported tracer at different rates. Labeling of motoneurons with a long-lasting, noncytotoxic fluorochrome such as the carbocyanine dyes used by Honig and Hume (1986) might permit both FACS enrichment and identification in heterogeneous cultures.

\section{Purity of sorted motoneurons}

It is important but difficult to compare the purity achieved by this method for isolating motoneurons with that obtained by other published methods. The alternative methods are based on the fact that motoneurons are larger and therefore have a greater rate of sedimentation than other cells from the spinal cord (Berg and Fischbach, 1978; Schnaar and Schaffner, 1981). The criterion for judging purification has normally been enrichment for ChAT, the synthetic enzyme for acetylcholine and a marker for cholinergic neurons. However, in the present case, enrichment for enzyme activity may not be a good indication of purity for 2 reasons. First, our labeling technique is expected to be exclusive rather than inclusive; we do not expect this method necessarily to label all the motoneurons in the spinal cord. Second, there are presumably other cholinergic neurons, such as preganglionic sympathetic neurons, in the unlabeled population. Nevertheless, this procedure did lead to a 4-fold higher level of ChAT activity per cell in the sorted, labeled cells than in sorted, unlabeled cells. This enrichment is similar to that found for the isolation of motoneurons by density-gradient and velocity sedimentation (Berg and Fischbach, 1978; Schnaar and Schaffner, 1981). Moreover, the procedure used here led to an estimated 40-50-fold enrichment in terms of the fraction of cells expressing immunoreactive ChAT. The population of sorted cells was over $80 \%$ pure with respect to the presence of fluorescent label in cells examined with fluorescence microscopy immediately after sorting. These results for purity and enrichment are the same as those published by McPheeters and Okun (1980) and Calof and Reichardt (1984) for the isolation of embryonic chick motoneurons. The values are slightly less than those published by O'Brien and Fischbach (1986), who reported that $90-95 \%$ of the cells in cultures seeded with sorted chick motoneurons contained fluorescent granules $1 \mathrm{~d}$ after plating. 

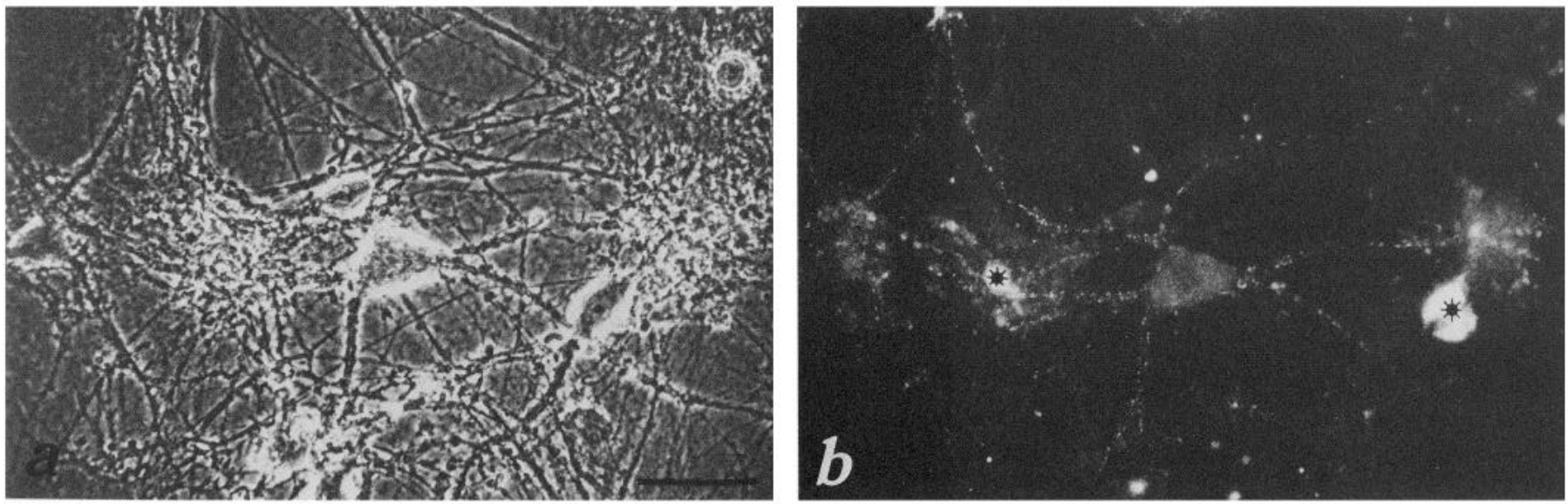

Figure 12. Sorted motoneurons labeled with antibody $2 \mathrm{~b}$ against the glycine-receptor protein. Labeling was performed without prior fixation of the cultures. $a$, Phase-contrast photomicrograph of a 3-week-old culture. $b$, The same field showing fluorescent anti-glycine-receptor immunoreactivity. Most of the cell bodies and processes appear to have surface labeling, but to varying extents. The asterisks in $b$ label highly fluorescent debris. Calibration bar, $50 \mu \mathrm{m}$.

It would be of great value to have some independent means of assessing the motoneuronal and cholinergic character of the sorted, labeled cells. One approach might be a quantitative assessment of the efficacy for forming functional cholinergic syn- apses in cocultures of sorted motoneurons with their natural target, skeletal muscle. We are currently developing the conditions for such cultures.

The identity and source of the smaller neurons in the sorted
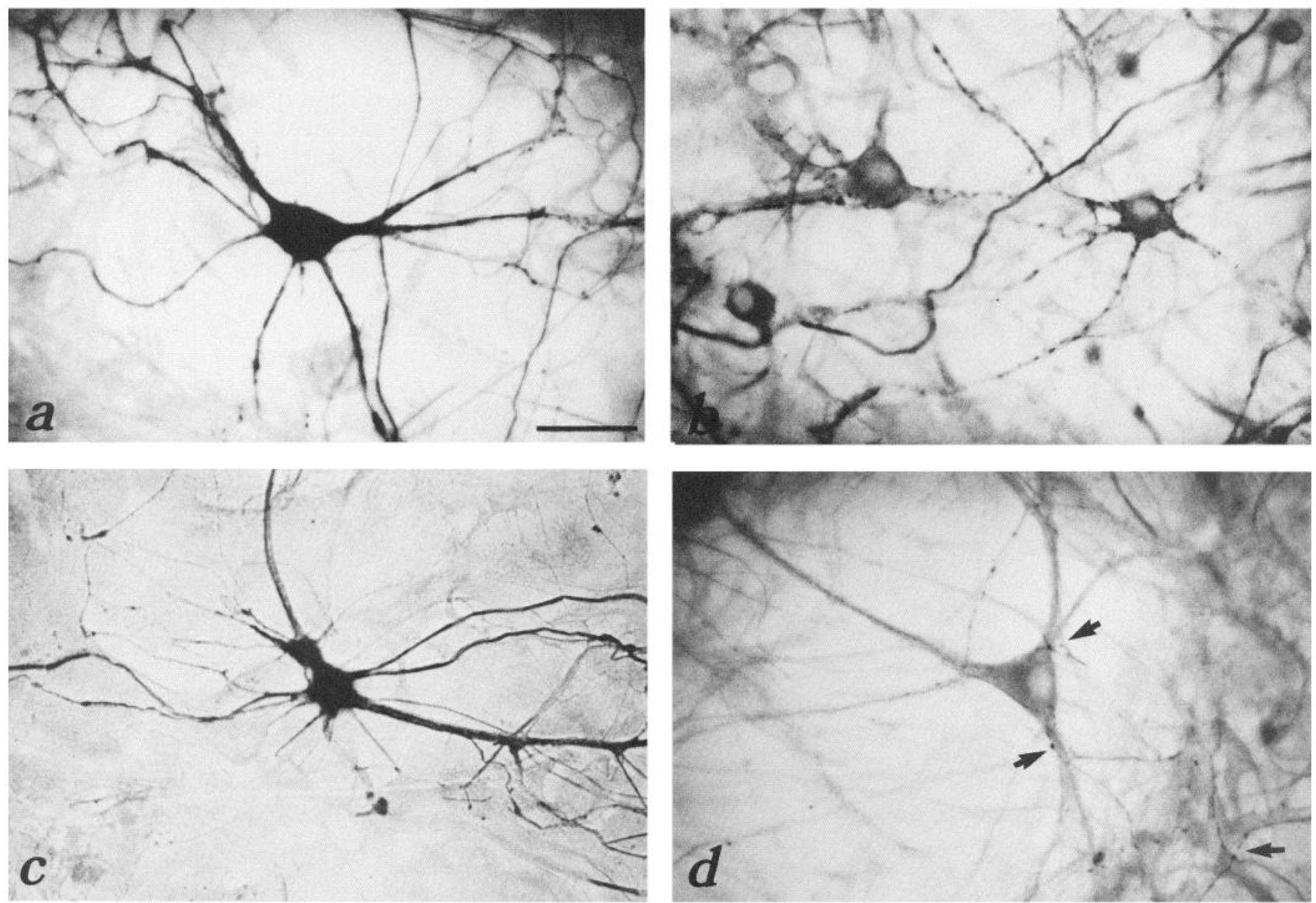

Figure 13. Three-week-old sorted mouse motoneurons fixed and labeled with antibodies against ChAT. $a$, A large, and $c$, a smaller intensely reactive ChAT-containing cell. $b$, Examples of cells slightly reactive for intracellular ChAT whose surfaces are studded with intensely reactive, ChAT-containing puncta that resemble bouton-like structures. $d$, A large, multipolar cell that is not stained above background but whose processes possess ChAT-immunoreactive puncta or are overlaid with ChAT-immunoreactive processes from another neuron (arrowheads). Calibration bar, $50 \mu \mathrm{m}$. 
population, many of which are GAD-positive, are not clear. They could be small $\gamma$-motoneurons, which are known to be significantly smaller than $\alpha$-motoneurons in the mouse (McHanwell and Biscoe, 1981). They might be small interneurons from the ventral horn (McHanwell and Biscoe, 1981) that have very short axons and could have been labeled by transsynaptic movement of the tracer. Although we have determined by microscopic examination that the cell suspensions used for sorting contain very few aggregates, it is also possible that some cells that were not labeled adhered to motoneurons and were isolated with them during sorting.

\section{Survival of sorted motoneurons}

Several laboratories have reported that muscle-conditioned medium or muscle extracts are important for both the adhesion and the survival of motoneurons in vitro. Calof and Reichardt (1984) found that sorted chick motoneurons responded to 2 distinct activities in muscle-conditioned medium: a neuritepromoting factor and a survival factor. Eagleson and Bennett (1983) reported that muscle-conditioned medium allowed the survival of twice as many sorted motoneurons from adult mouse as did normal medium over a $24 \mathrm{hr}$ period, and Nurcombe et al. (1985) reported that myotube-conditioned medium promoted survival and neuritic outgrowth of dissociated chick motoneurons in culture, identified by prior labeling with HRP. Skeletal muscle extracts have recently been shown to maintain motoneuron survival and induce cholinergic differentiation (ChAT immunoreactivity) in vitro (Smith et al., 1986). It was recently reported that cultures of astrocytes from the developing avian spinal cord or conditioned medium from these cultures enhanced the survival of motoneurons (identified by retrogradely transported HRP) for $48 \mathrm{hr}$ after plating (Tanaka and Obata, 1983; Eagleson et al., 1985). However, only muscle-conditioned medium allowed survival for longer periods. We also found that muscle-conditioned medium and astrocyte feeders together were critical for initial adhesion and neurite extension, as well as for long-term survival of the sorted embryonic mouse motoneurons.

Other investigators have observed that in chick motoneuronal cultures, the number of surviving neurons remaining in the cultures does decline rather precipitously after a few days in culture (Calof and Reichardt, 1984; O'Brien and Fischbach, 1986). Although cell death occurs in our motoneuron cultures, we have not quantified the decline, since there were large numbers of neurons remaining for electrophysiological and immunocytochemical studies.

Cell death of developing motoneurons in situ can be avoided by grafting on additional target material (Hollyday and Hamburger, 1976) or suppressing muscle activity (Pittman and Oppenheim, 1978, 1979; Oppenheim and Maderdrut, 1981). Cell death of developing ciliary ganglion neurons can be blocked in vitro by addition of target cells or medium conditioned by these cells (Nishi and Berg, 1979; Barbin et al., 1984; Manthorpe and Varon, 1985). It will be interesting to determine whether the naturally occurring death of sorted motoneurons follows the same pattern in vitro and whether cell death can be blocked in similar ways.

\section{Immunocytochemical characteristics}

The motoneurons isolated by our technique share many characteristics of motoneurons in vivo. Immunocytochemistry indicates that most of the putative motoneurons are literally out- lined with what appear to be GAD-positive boutons; these arise from a few small cells that appear to be contaminants in the sorted population. This observation suggests that isolated motoneurons in vitro may receive functional GABAergic innervation. There is evidence that, in vivo, rat motoneurons have GAD-containing boutons on their dendrites and somas (Wood, 1976).

It has been reported that spinal motoneurons in the mouse and human contain immunoreactive GAD (Chan-Palay et al., 1982a) and that motoneurons in the monkey contain measurable levels of GAD enzymatic activity (Murashima and Kato, 1985). This neurotransmitter-synthesizing enzyme has also been described by immunohistochemistry at human and monkey neuromuscular junctions (Chan-Palay et al., 1982b). Among the motoneurons isolated in the present experiments, large multipolar neurons displayed no GAD immunoreactivity, even under conditions that revealed GAD in the cell bodies of small neurons. By use of the more sensitive avidin-biotin method, however, intrinsic GABA immunoreactivity was detected in a small number of these large motoneurons. Presumably these few cells also contain GAD.

Many of the sortcd ncurons have glycinc receptors on their cell bodies and processes, as judged from labeling by antibodies against the glycine receptor. This agrees with pharmacological data on the glycine sensitivity of mammalian motoneurons in situ (Curtis, 1959; Krnjevic, 1976; Takahashi, 1984), and with antibody labeling seen on motoneurons in situ (Triller et al., 1985 ) and on "mixed" cultures of spinal neurons in vitro (P. A. St. John, unpublished observations). Discrete areas of sensitivity to applied glycine have been seen on spinal neurons in vitro (Macdonald and Barker, 1981).

Immunohistochemical staining indicates that in 3-week-old "motoneuron" cultures, a much higher percentage of cells contain immunoreactive ChAT than do whole spinal cord cultures grown under the same conditions. This indicates that neurons containing this cholinergic enzyme have been significantly enriched by this procedure. We do not know, however, why such a small percentage of neurons in either culture are ChAT-positive. It could be that the purity of the sorted cells is much lower than we have estimated (see above), but we feel that such a large discrepancy is unlikely and that other explanations are more likely. For example, it is possible that in many cells the enzyme is present at very low levels, not detected by our immunohistochemical methods. Smith et al. (1986), using monoclonal antiChAT antibodies from a different source, found that in cultures from embryonic rats, over $7 \%$ of cells in whole cord cultures and $17.5 \%$ of the cells in ventral spinal cord cultures (enriched for motoneurons) were immunoreactive. Perhaps this antibody would label a greater proportion of our sorted motoneurons. It is also possible that contact with skeletal muscle, resulting in synaptic activity or release of trophic factors, is necesary for greater production of the enzyme.

In the future, it should be possible to include a selectively back-labeled, sorted subpopulation of sensory neurons from the dorsal root ganglia in these cultures, since about $30 \%$ of the dorsal root ganglia stain with the same protocol used for motoneurons. Eventually it may be possible to reconstruct specific sensory-motoneuromuscular reflex arcs in vitro, since many of the labeled dorsal root ganglia should be those that give rise to the muscle afferents. In a separate paper, an initial survey of the clcctrically cxcitable membrane properties of sorted motoneurons is presented (Owen et al., 1984). 


\section{References}

Barbin, G., M. Manthorpe, and S. Varon (1984) Purification of the chick eye ciliary ncuronotrophic factor (CNTF). J. Neurochem. 43: 1468-1478.

Barnstable, C. J. (1980) Monoclonal antibodies which recognize different cell types in the rat retina. Nature 286: 231-235.

Berg, D. K., and G. D. Fischbach (1978) Enrichment of spinal cord cell cultures with motoneurons. J. Cell Biol. 77: 83-98.

Bottenstein, J. E., and G. Sato, eds. (1985) Cell Culture in the Neurosciences, Plenum, New York.

Bruce, G., B. H. Wainer, and L. B. Hersh (1985) Immunoaffinity purification of human choline acetyltransferase: Comparison of the brain and placental enzymes. J. Neurochem. 45: 611-620.

Calof, A. L., and L. F. Reichardt (1984) Motoneurons purified by cell sorting respond to two distinct activities in myotube-conditioned medium. Dev. Biol. 106: 194-210.

Chan-Palay, V., A. G. Engel, S. L. Palay, and J. Y. Wu (1982a) Synthesizing enzymes for four neuroactive substances in motor neurons and neuromuscular junctions: Light and electron microscopic immunocytochemistry. Proc. Natl. Acad. Sci. USA 79: 6717-6721.

Chan-Palay, V., A. G. Engel, J. Y. Wu, and S. L. Palay (1982b) Coexistence in human and primate neuromuscular junctions of enzymes synthesizing acetylcholine, catecholamine, taurine, and $\gamma$-aminobutyric acid. Proc. Natl. Acad. Sci. USA 79: 7027-7030.

Cohen, J., and S. Y. Selvendran (1981) A neuronal cell-surface marker is found in the CNS but not in peripheral neurons. Nature 291: 421423.

Conner, J. A., and C. F. Stevens (1971) Voltage clamp studies of a transient outward membrane current in gastropod neural somata. J. Physiol. (Lond.) 213: 21-30.

Curtis, D. R. (1969) Pharmacological investigations upon inhibition of spinal motoneurons. J. Physiol. (Lond.) 145: 175-192.

Derby, M. A., S. A. Dyer, and L. Glaser (1983) Monoclonal antibodies against a differentiated retinal cell population. Dev. Biol. 7: 317-325.

Dodd, J., and T. M. Jessell (1985) Lactoseries carbohydrates specify subsets of dorsal root ganglion neurons projecting to the superficial dorsal horn of rat spinal cord. J. Neurosci. 5: 3278-3294.

Eagleson, K. L., and M. R. Bennett (1983) Survival of purified motor neurones in vitro: Effects of skeletal muscle-conditioned medium. Neurosci. Lett. 38: 187-192.

Eagleson, K. L., T. R. Raju, and M. R. Bennett (1985) Motoneurone survival is induced by immature astrocytes from developing avian spinal cord. Dev. Brain Res. 17: 95-104.

Fields, K. (1985) Neuronal and glial surface antigens on cells in culture. In Cell Culture in the Neurosciences, J. E. Bottenstein and G. Sato, eds., pp. 45-93, Plenum, New York.

Flanagan, A. E. H. (1969) Differentiation and degeneration in the motor horn of the foetal mouse. J. Morphol. 129: 281-306.

Hawkes, R., E. Niday, and A. Matus (1982) Monoclonal antibodies reveal novel neural antigens. Proc. Natl. Acad. Sci. USA 79: 24102414.

Heuser, J. E. (1976) Synaptic vesicle exocytosis revealed in quickfrozen frog neuromuscular junctions treated with 4-aminopyridine and given a single electrical shock. In Society for Neuroscience Symposia, vol. 2, W. M. Cowan and J. A. Ferrendelli, eds., pp. 215-239, Society for Neuroscience, Bethesda, MD.

Hollyday, M., and V. Hamburger (1976) Reduction of the naturally occurring motor neuron loss by enlargement of the periphery. J. Comp. Neurol. 170: 311-320.

Honig, M. G., and R. I. Hume (1986) Fluorescent carbocyanine dyes allow living neurons of identified origin to be studied in long-term cultures. J. Cell Biol. 103: 171-187.

Krnjevic, K. (1976) Transmitters in motor systems. In Handbook of Physiology-The Nervous System, vol. 2, American Physiological Society, Baltimore, MD, pp. 107-154.

Lance-Jones, C. (1982) Motoneuron cell death in the developing lumbar spinal cord of the mouse. Dev. Brain Res. 4: 473-479.

Landis, D. M. D., and L. A. Weinstein (1983) Membrane structure in cultured astrocytes. Brain Res. 276: 31-41.

Macdonald, R. L., and J. L. Barker (1981) Neuropharmacology of spinal cord neurons in primary dissociated cell culture. In Excitable Cells in Tissue Culture, P. G. Nelson and M. Lieberman, eds., pp. 81-110, Plenum, New York.

Manthorpe, M., and S. Varon (1985) Regulation of neuronal survival and neuritic growth in the avian ciliary ganglion by trophic factors.
In Growth and Maturation Factors, vol. 3, G. Guroff, ed., pp. 77117, Wiley, New York.

McHanwell, S., and T. J. Biscoe (1981) The sizes of motoneurons supplying hindlimb muscles in the mouse. Proc. R. Soc. Lond. [Biol.] 213: 201-216.

McKay, R., and S. V. Hockfield (1982) Monoclonal antibodies distinguish antigenically discrete neuronal types in the vertebrate central nervous system. Proc. Natl. Acad. Sci. USA 79: 6747-6751.

McPheeters, M., and L. M. Okun (1980) Identification and isolation in vitro of presumptive motoneurons marked by retrograde transport of a new fluorescent tracer. Soc. Neurosci. Abstr. 6: 733.

Miller, T. M., and J. E. Heuser (1984) Endocytosis of synaptic vesicle membrane at the frog neuromuscular junction. J. Cell Biol. 98: 685698.

Murashima, Y. L., and T. Kato (1985) Glutamate decarboxylase activities in single vertebrate neurons. J. Neurochem. 45: 732-738.

Neale, E. A., G. Bruce, E. Matthews, S. W. d'Autremont, W. L. Strauss, L. B. Hersh, and P. G. Nelson (1985) Cholinergic neurons demonstrated by immunohistochemistry in mouse spinal cord cultures. Soc. Neurosci. Abstr. 11: 862.

Nelson, P. G., and M. Lieberman, eds. (1981) Excitable Cells in Tissue Culture, Plenum, New York.

Nishi, R., and D. K. Berg (1979) Survival and development of ciliary ganglion neurons grown alone in cell culture. Nature 277: 232-234.

Nurcombe, V., S. Tout, and M. R. Bennett (1985) Motoneurone survival and neuritic outgrowth promoted by different cell types in embryonic muscle. Dev. Brain Res. 21: 49-60.

O'Brien, R. J., and G. D. Fischbach (1986) Isolation of embryonic chick motoncurons and their survival in vitro. J. Neurosci. 6: $3265-$ 3274.

Oertel, W. H., D. E. Schmechel, E. Mugnaini, M. L. Tappaz, and I. J. Kopin (1981) Immunocytochemical localization of glutamate decarboxylase in rat cerebellum with a new antibody. Neuroscience 6: 2715-2735.

Okun, L. M. (1981) Identification and isolation in vitro of neurons marked in situ by retrograde transport. In New Approaches in Developmental Neurobiology, Society for Neuroscience, Bethesda, MD, pp. 109-121.

Oppenheim, R. W. (1986) The absence of significant postnatal motoneuron death in the brachial and lumbar spinal cord of the rat. $J$. Comp. Neurol. 246: 281-286.

Oppenheim, R. W., and J. L. Maderdrut (1981) Pharmacological modulation of neuromuscular transmission and cell death in the lateral motor column of the chick embryo. Soc. Neurosci. Abstr. 7: 291

Owen, D. G., A. E. Schaffner, P. A. St. John, and J. L. Barker (1984) Current- and voltage-clamp analyses of putative motoneurones cultured from the embryonic mouse spinal cord. Soc. Neurosci. Abstr. 10:7.

Peacock, J. H., P. G. Nelson, and M. W. Goldstone (1973) Electrophysiologic study of cultured neurons from spinal cords of fetal mice. Dev. Biol. 30: 137-152.

Pfeiffer, F., D. Graham, and H. Betz (1982) Purification by affinity chromatography of the glycine receptor of rat spinal cord. J. Biol. Chem. 257: 9389-9393.

Pittman, R., and R. W. Oppenheim (1978) Neuromuscular blockade increases motoneurone survival during normal cell death in the chick embryo. Nature 271: 364-366.

Pittman, R., and R. W. Oppenheim (1979) Cell death of motoneurons in the chick embryo spinal cord. IV. Evidence that a functional neuromuscular interaction is involved in the regulation of naturally occurring cell death and stabilization of synapses. J. Comp. Neurol. 187: 425-446.

Rogawski, M. A., and J. L. Barker (1983) Effects of 4-aminopyridine on calcium action potentials and calcium current under voltage clamp in spinal neurons. Brain Res. 280: 180-185.

Romijn, H. J., F. van Huizen, and P. S. Wolters (1984) Towards an improved serum-free, chemically defined medium for long-term culturing of cerebral cortex tissue. Neurosci. Biobehav. Rev. 8: 301334.

St. John, P. A., W. M. Kell, J. S. Mazzetta, G. D. Lange, and J. L. Barker (1986) Analysis and isolation of embryonic mammalian neurons by fluorescence-activated cell sorting. J. Neurosci. 6: 1492-1512.

Schachner, M. (1982) Cell type-specific surface antigens in the mammalian nervous system. J. Neurochem. 39: 1-8.

Schaffner, A. E., and R. L. Schnaar (1983) The isolation and purifi- 
cation of neurons from the vertebrate central nervous system. In Current Methods in Cellular Neurobiology, J. L. Barkcr, cd., pp. 131185, Wiley, New York.

Schaffner, A. E., P. A. St. John, and J. L. Barker (1983) Purification of embryonic mouse motoneurons by flow cytometry. Soc. Neurosci. Abstr. 9: 7.

Schmechel, D. E., P. J. Marangos, A. P. Zis, M. W. Brightman, and F. K. Goodwin (1978) Brain enolases as specific markers for neuronal and glial cells. Science 199: 313-315.

Schmechel, D. E., M. W. Brightman, and J. L. Barker (1980) Localization of neuron-specific enolase in mouse spinal neurons grown in tissue culture. Brain Res. 181: 391-400.

Schnaar, R. L., and A. E. Schaffner (1981) Separation of cell types from embryonic chicken and rat spinal cord: Characterization of motoneuron-enriched fractions. J. Neurosci. 1: 204-217.

Schrier, B., S. H. Wilson, and M. Nirenberg (1974) Cultured cell systems and methods for neurobiology. Methods Enzymol. 32: 765788 .

Segal, M., M. A. Rogawski, and J. L. Barker (1984) A transient potassium conductance regulates the excitability of cultured hippocampal and spinal neurons. J. Neurosci. 4: 604-609.

Smith, R. G., K. Vaca, J. McManaman, and S. H. Appel (1986) Selective effects of skeletal muscle extract fractions on motoneuron development in vitro. J. Neurosci. 6: 439-447.
Sternberger, L. A. (1974) Immunocytochemistry, Prentice-Hall, Englewood Cliffs, NJ, pp. 129-171.

Stewart, W. W. (1978) Functional connections between cells as revealed by dye-coupling with a highly fluorescent naphthalimide tracer. Cell 14: 741-759.

Stewart, W. W. (1981) Lucifer dyes-highly fiuorescent dyes for biological tracing. Nature 292: 17-21.

Takahashi, T. (1984) Inhibitory miniature synaptic potentials in rat motoneurons. Proc. R. Soc. Lond. [Biol.] 221: 103-109.

Tanaka, H., and K. Obata (1983) Survival of HRP-labeled spinal motoneurons of chick embryo in tissue and cell culture. Dev. Brain Res. 9: 390-395.

Thesleff, S. (1980) Aminopyridines and synaptic transmission. Neuroscience 5: 1413-1419.

Triller, A., F. Cluzeaud, F. Pfeiffer, H. Betz, and H. Korn (1985) Distribution of glycine receptors at central synapses: An immunoclectron microscopy study. J. Cell Biol. 101: 683-688.

Wood, J. G., B. J. McLaughlin, and J. E. Vaughn (1976) Immunocytochemical localization of GAD in electron microscopic preparations of rodent CNS. In GABA in Nervous System Function, E. Roberts, T. N. Chase, and D. B. Tower, eds., pp. 133-148, Raven, New York. 